\title{
Insects affecting regenerating conifers in Canada: natural history and management
}

\author{
René I. Alfaro, ${ }^{1}$ Alvaro Fuentealba
}

\begin{abstract}
A number of insect species in a variety of families and orders damage early regenerating forests. Successful management of pests of regenerating forests requires detailed information on the natural history of the damaging organism, including the factors that increase risk, and a careful assessment of the risk mitigation options. Decision support systems, in the form of stand models capable of incorporating pest management options are required to guide decisions in terms of the expected yields under various pest management scenarios. In this paper we review research to date on the natural history and damage of the most important insect pests of regenerating forests in Canada and propose a framework for risk assessment. Canadian scientists have been active contributors to the research that advanced this field, from the early descriptive studies, to the development of practical tools to assist industry in managing pests of young forests.
\end{abstract}

\section{Introduction}

Forestry is a major industry in Canada, providing significant benefits to society by generating direct and indirect employment and contributing CDN $\$ 19.8$ billion, or $1.25 \%$, to Canada's real gross domestic product (Natural Resources Canada 2014). Canadians also value the many ecosystem services provided by forests. These include water, recreation, habitat for wildlife, carbon sequestration, and others.

Forests are continuously subjected to natural disturbances, such as fire or insect epidemics, or to anthropogenic disturbances, such as harvesting and salvage logging, and reforestation is of paramount importance for maintaining a continuous productive cycle following disturbance. For example, restoration of areas of widespread tree mortality caused by the recent large outbreak of mountain pine beetle, Dendroctonus ponderosae Hopkins (Coleoptera: Curculionidae), which began in British Columbia (BC) in the 1990s, will need sustained investments in reforestation.

Lately, there is an increased interest in Canada, particularly in reforestation with fast growing plantations, such as poplars, for bioenergy production, and for climate change mitigation through increased carbon dioxide uptake by fast growing trees (Volney et al. 2005). These investments are bringing into focus the need for protecting young stands through pest management.

As it is the norm in forest ecosystems, most insects present in young stands have few negative effects on forests; many are beneficial, contributing to important ecosystem functions, such as nutrient cycling, or acting as pollinators, while others contribute to overall forest health by acting as effective parasitoids or predators of pests. However, some insects often escape natural controls and take advantage of the often favourable conditions created by silviculture, such as the creation of single species stands, to increase in numbers to the point where they became damaging to young stands, hindering reforestation efforts, forest productivity, and reducing economic benefits. These negative effects range from killing of seedlings and young trees, to causing growth reductions and stem deformities, which can significantly reduce the future merchantable timber value. Some insects, such as the white pine weevil, Pissodes strobi (Peck) (Coleoptera: Curculionidae),

Received 22 January 2015. Accepted 13 May 2015. First published online 27 July 2015.

R.I. Alfaro, ${ }^{1}$ Canadian Forest Service, Pacific Forestry Centre, 506 W Burnside Rd. Victoria, British Columbia, Canada V8Z 1M5

A. Fuentealba, Département des sciences du bois et de la forêt, Faculté de foresterie, de géographie et de géomatique, Pavillon Abitibi-Price, 2405 rue de la Terrasse, Université Laval, Ville de Québec, Québec, Canada G1V 0A6

${ }^{1}$ Corresponding author (e-mail: Ralfaro@nrcan.gc.ca).

Langor, D.W. and Alfaro, R.I. (eds.) Forest Entomology in Canada: Celebrating a Century of Science Excellence doi: $10.4039 /$ tce. 2015.50 
can produce substantial damage, particularly height growth losses through girdling of the apical tree leader (Alfaro et al. 1995).

Management of young stands requires an understanding of the natural history and impacts of the pests affecting them. This paper reviews the natural history of the main groups of pests of young conifer (Pinaceae) stands in Canada and provides examples of damage assessment and management of particular pests, and proposes a framework for risk assessment of insects affecting regenerating forests.

\section{Natural history and damage caused by insect pests of young stands}

Pest insects of young forests are generally classified according to the part of the seedling or tree upon which they feed. This system allows for a better understanding of the relationship between the insect and its host.

\section{Root and root collar insects}

Root and root collar insects attack tree roots either from the outside or by boring inside the root. They can consume the entire root or just part of it. Normally it is the larvae of these insects that damage the roots, whereas the adults feed on the bark of small branches, twigs, foliage, or flowers, or do not feed at all (Furniss and Carolin 1977; Coulson and Witter 1984; Drooz 1985). Removal of root tissue by these insects can induce several responses in their host plants, including changes in root:shoot ratios, with subsequent changes in carbon and nitrogen allocation that can ultimately result in the death of the plants (Hunter 2001). Injury to roots and root collars in temperate and boreal forest trees is mainly caused by insects belonging to the order Coleoptera and, more specifically, root-collar weevils in the genus Hylobius Germar (Coleoptera: Curculionidae), and root beetles in the genus Hylastes Erichson (Coleoptera: Curculionidae) (Hunter 2008). The effects of these insects are more severe on young trees than on old individuals (Coulson and Witter 1984).

\section{Root-collar and seedling debarking weevils, Hylobius species}

Warren root collar weevil (Hylobius warreni (Wood)) is a significant pest of pines in Canada.
This insect occurs across Canada, from Newfoundland and Labrador, to coastal British Columbia (Furniss and Carolin 1977; Cerezke 1994). It can attack most pine and spruce species that are native to Canada, but the most susceptible hosts are lodgepole pine, Pinus contorta var. latifolia Engelmann; jack pine, Pinus banksiana Lambert; and white spruce, Picea glauca (Moench) Voss (all Pinaceae) (Cerezke 1994). The life cycle of this insect typically is completed in two years, but adult weevils can live for up to five years (Cerezke 1994). Developing larvae inflict the most damage to a tree by feeding on the phloem around the large lateral roots of the host or at the root collar. As the insects mature, their feeding galleries become deeper, and they may score the xylem tissues (Warren 1956; Cerezke 1994). Wounds that are caused by larvae can allow the entry and development of root-rotting fungal infections (Whitney 1961; Coulson and Witter 1984). The adults are flightless and thus vision plays an important role in host finding behaviour (Machial et al. 2012). They continue to feed on the bark of roots and twigs, and on the needles of the host (Furniss and Carolin 1977). Healthy trees are susceptible to infestation at a young age, with these trees frequently being subject to repeated attacks at irregular intervals through to stand maturity or harvest (Cerezke 1970, 1994). In young trees, complete girdling can be accomplished by as few as one to three larvae (Cerezke 1994). In trees with larger diameters, many more weevils are required to complete girdling, although insects rarely occur at high densities. Warren root collar weevils can cause mortality in stands as old as 30 years of age, although peak mortality occurs in five-year-old to 10-year-old stands (Ives and Rentz 1993).

Historically, Warren root collar weevil was thought to be of minor economic concern. For example, Hall et al. (1998) reported that weevilrelated mortality in lodgepole pine stands was $<1 \%$ per year in central interior British Columbia, and Ives and Rentz (1993) also reported very low mortality $(<0.5 \%$ incidence in five-year age classes) by this weevil in immature lodgepole pine stands (up to 25 years old) of west-central Alberta. In recent years, however, feeding activity and subsequent mortality from this insect has increased to levels as high as $16 \%$ in young stands in central British Columbia (Schroff et al. 2006). 
This trend may be related to the increase in areas replanted with young lodgepole pines in western Canada to replace dead trees that were salvaged following the outbreak of mountain pine beetle in this region. Increased migration of Warren root collar weevils that are in search of food has been observed, moving from unsalvaged stands killed by mountain pine beetle to young, reforested stands (Klingenberg et al. 2010), leading to increased mortality of young trees. However, it has been observed that mortality in young stands tends to decrease with increasing distance from the stand edges (McCulloch et al. 2009).

Pales weevil, Hylobius pales Herbst, is the most serious pest of pine seedlings in recently cut-over sites, reforested areas, and Christmas tree plantations (Drooz 1985). This insect is distributed throughout eastern North America. In Canada, this insect occurs from Nova Scotia to Manitoba (Finnegan 1959). In southern Ontario, the weevil has been found feeding on white pine, Pinus strobus Linnaeus; red pine, Pinus resinosa Aiton; jack pine; Austrian pine, Pinus nigra Arnold; Scots pine, Pinus sylvestris Linnaeus; and tamarack or eastern larch, Larix laricina (Du Roi) Koch (all Pinaceae) (Finnegan 1959). Damage is caused by the adults that feed on the bark of young seedlings, thereby girdling the stem above or below the ground surface, often leading to the death of the host. Although feeding occurs on the branches of large trees, injury caused by pales weevil is most serious on seedlings (Coulson and Witter 1984). Seedling mortality of 30-60\% is not uncommon in plantations and mortality rates of over $90 \%$ have been reported (Ciesla 2011). In Canada, damage produced by this weevil has been mostly associated with Christmas tree plantations where the insect can find a continuous supply of breeding material. For example, an epidemic outbreak of this insect killed or discoloured up to $40 \%$ of the branches of five-year-old to 10 -yearold pines in Christmas tree plantation in southern Ontario (Finnegan 1959).

Other species of Hylobius found in Canada include the seedling debarking weevil, $H$. congener Dalla Torre, Schenkling, and Marshall; the pine root collar weevil, $H$. radicis Buchanan; and the Couper collar weevil, H. pinicola Couper (Warren 1960). The seedling debarking beetle feeds on red, white, and Scots pines (Martin 1964) but it can also be found in larch and spruce (Drooz 1985).
The adults feed on the inner bark, removing irregular patches of the bark (Martin 1964), girdling the seedling. The attack of this insect does not always results in the death of the seedling because the debarked stem may form callus that covers the wounded area (Welty and Houseweart 1985). This weevil has caused economic injury mainly in the Maritime Provinces of Canada. Damage produced by this insect was first reported in Nova Scotia in 1984 when seedling mortality exceeded $85 \%$ in some plantations (Magasi 1989). In 1986, the seedling debarking weevil caused high mortality in 29 sites in Newfoundland and Labrador and in Nova Scotia (Magasi 1995). The three Maritime Provinces reported damage produce by the weevil in 1988 . However, Nova Scotia was the most affected of them, reporting losses as high as $90 \%$ of the seedling planted in some sites (Magasi 1989). The use of traps and lures for predicting expected levels of mortality produced by the weevil is currently recommended before planting stocks (Penny 2007). The pine root collar weevil attacks many species of pines, including Scots pine; Austrian pine; mugo pine, Pinus mugo Turra; jack pine; pitch pine, $P$. rigida Miller; red pine; white pine; and lodgepole pine. Host mortality occurs from extensive damage on growth and transport tissues while larvae bore into the phloem and cambium of the root collar and roots (Wilson and Millers 1983). Economic damage produced by this insect has been observed in Canada. For example, pine root collar weevil incurred mortality in up to $25 \%$ of hosts in Manitoba and up to $90 \%$ in Scots and red pine plantations in southern Ontario (Prentice 1955; Finnegan 1962). The Couper collar weevil attacks most coniferous trees, including members of the genera Pinus Linnaeus, Picea Dietrich, Abies Miller, and Larix Miller (all Pinaceae) (Warren 1960; Grant 1966). However, economic damage has been reported on balsam fir, Abies balsamea (Linnaeus) Miller; black spruce, Picea mariana (Miller) Britton, Sterns, and Poggenburg; tamarack, Larix laricina (Du Roi) Koch; and white spruce (Cerezke and Pendrel 1995). The damage is produced by the larvae by feeding on the phloem around the large lateral roots of the host or at the root collar (Warren 1960). Although this weevil is considered of minor economic concern, some stands can be heavily impacted. For example, this insect has been reported attacking balsam fir roots 
in stands 6-55 years old where 6-77\% of tree root systems were injured. Furthermore, some injuries by this weevil can remain exposed to infection by wood-destroying fungi (Smerlis 1961).

The weevil Steremnius carinatus (Boheman) (Coleoptera: Curculionidae) has also been reported to cause damage to conifer seedlings in plantations and young natural regeneration (Condrashoff 1968; Cerezke and Pendrel 1995). The weevil occurs only in western Canada, mainly along the mainland of British Columbia, but also on Vancouver Island, the Queen Charlotte Islands, and interior southeastern wet belt of the province (Cerezke and Pendrel 1995). It mainly attacks Douglas-fir, Pseudotsuga menziesii (Mirbel) Franco; Sitka spruce, Picea sitchensis (Bongard) Carrière; amabilis fir, Abies amabilis Douglas ex Forbes; and western hemlock, Tsuga heterophylla (Rafinesque) Sargent (all Pinaceae) (Condrashoff 1968; Cerezke and Pendrel 1995). The weevil was considered a scavenger until it was observed damaging Douglas-fir seedling on Vancouver Island in 1961 (Lejeune 1962). The economic damage is produced by the adult that girdles the main stem of the seedling from $1 \mathrm{~cm}$ below to $2-3 \mathrm{~cm}$ above ground level (Condrashoff 1968). The first reports of damage produced by the weevil in Vancouver Island indicated that the insect has killed or damaged over $40 \%$ of Douglas-fir seedlings planted (Lejeune 1962; Condrashoff 1968). Furthermore, over $50 \%$ of young natural regeneration (cedar, hemlock, and Sitka spruce) was attacked and $25 \%$ of attacked Sitka spruce seedlings were completely girdled and killed in the Queen Charlotte Islands (Condrashoff 1968). In 1983, an average of 6\% of recently planted conifer seedling were killed by the weevil in 17 of the 30 sites surveyed, being the seedlings of amabilis fir and western hemlock the most affected $(12 \%$ and $10 \%$ mortality in average respectively). Four plantations were later surveyed that year, reporting that severe basal girdling by the weevil affected in average $29 \%$ of the amabilis fir, $18 \%$ of the western hemlock, and $5 \%$ of the Sitka spruce seedlings (Wood et al. 1984). In 1985, the weevil killed up to $9 \%$ of the seedling in 12 plantations on Vancouver Island, with amabilis fir being the most affected species reaching $40 \%$ mortality in one plantation. Other species affected by the weevil were Douglas-fir; western hemlock; western red cedar,
Thuja plicata (Donn ex Don); Sitka spruce; and grand fir, Abies grandis (Douglas ex Don) Lindley (Wood and Van Sickle 1986).

\section{Root-feeding insects attacking seedlings}

Root feeding beetles in the genus Hylastes, along with seedling debarking weevils, are amongst the most important pests of coniferous seedlings in North America, producing high mortality.

The genus Hylastes has 15 known species in North America (Blackman 1941). Hylastes bark beetles infest conifers, mostly in the genera Pinus and Picea. These beetles are usually found in the roots and bases of dead or dying trees or in the stumps and roots of cut trees, where they breed (Drooz 1985). Adults of Hylastes can occasionally damage the roots, root collars, and stems of seedlings, resulting in the death of the individuals that have been attacked (Zethner-Møller and Rudinsky 1967); otherwise, they have been considered economically unimportant. Recent reports, however, have indicated that Hylastes species play an important role in loblolly pine (Pinus taeda Linnaeus) decline in the United States of America by transmitting vascular stain fungi to the trees (Leptographium Lagerberg and Melin (Ophiostomataceae)) (Eckhardt et al. 2004, 2007). In Canada, Hylastes nigrinus (Mannerheim) has been reported to be the vector of the black stain root disease pathogen Leptographium wageneri var. pseudotsugae Harrington and Cobb (Jacobi 1992). This disease is a serious forest management problem in southern British Columbia. Jacobi et al. (2008) reported overall mortality that could be attributed to black stain root disease in lodgepole pine on Vancouver Island and mainland British Columbia rose from $11.4 \%$ in 1989 to $19.0 \%$ in 2000 .

Other root-feeding insects that cause damage to tree seedlings are the non-native black vine weevil, Otiorhynchus sulcatus (Fabricius) (Coleoptera: Curculionidae) and the strawberry root weevil, O. ovatus (Linnaeus). These weevils are common horticultural pests and occasionally damage conifer seedlings in the field. Adults of both weevil species feed on the foliage and the tender bark of their host and lay their eggs in the 
soil near the seedling. The larvae, on the other hand, feed on the roots, which may severe the small roots and girdle the large one (Ives and Wong 1988). The black vine weevil has been reported on black spruce and Douglas-fir seedlings, respectively damaging $10 \%$ of the former and $25 \%$ of the latter species at the Pacific Forest Research Centre in Victoria, British Columbia (Erickson and Hughes 1982). Strawberry root weevil, which has been detected on conifer seedlings in British Columbia, can attack several conifer species and girdle the root collar under heavy infestations (Shrimpton 1985). In the Prairie Provinces, only strawberry weevil has been considered of any economic importance (Ives and Wong 1988).

\section{Insects causing damage to seedlings}

Seedlings can be attacked either below ground by root-feeding insects (see previous section) or above ground by cutworms, bark-chewing beetles, caterpillars, sawflies, and aphids, among others (Furniss and Carolin 1977). These attacks result in seedling mortality or reduced seedling quality. Given their small size, immature root systems, and small energy reserves, seedlings are more vulnerable than mature trees to insect attack; therefore, the presence of one or a few insects can inflict very serious damage to seedlings (Speight and Wainhouse 1989). The most common causes of seedling mortality are defoliation, cutting or girdling of the stem and injection of toxins. Sub-lethal effects, such as discolouration of foliage, stunting, bud damage, loss of foliage, and the production of multiple or crooked leaders, can significantly reduce seedling quality (Scarr et al. 2001).

\section{Cutworms}

Many of the insects that attack seedlings are polyphagous and sporadically become serious economic threats. One of the most prominent groups of insects damaging seedlings is the cutworms (Lepidoptera: Noctuidae). Cutworm caterpillars emerge from the soil at night to feed on seedling stems at or below the ground surface, usually cutting them down (hence the name cutworm) (Speight and Wainhouse 1989). These insects can pose serious problems for agricultural crops and occasionally damage nurseries and newly planted conifer seedlings (Coulson and Witter 1984). Occurring throughout Canada, the black army cutworm, Actebia fennica (Tauscher) is the most serious cutworm pest affecting conifer seedlings (Humble et al. 1989). It was not considered a forest pest until 1973 when an extensive outbreak occurred on recently planted spruce, lodgepole pine and Douglas-fir seedlings in British Columbia (Ross and Ilnytzky 1977). This insect is associated with burnt areas where its larvae appear 1-2 years after the fire (Humble et al. 1989). Larvae defoliate seedlings, destroy terminal and lateral buds, and occasionally chew the bark (Maher and Shepherd 1992).

Black army cutworm damage stunts root growth and new root establishment in the soil, leading to seedling mortality or height growth losses. Partial or complete replanting of seedlings may be required after severe damage (Humble et al. 1989). According to Maher and Shepherd (1992), seedling mortality or height losses occur when defoliation is $>60 \%$, or when the terminal bud is killed. These authors also found that there is significantly lower mortality if defoliation occurs at least one year after seedlings were planted, probably because the root system has become established by then. Another cutworm species that causes damage to seedlings in Canada is the variegated cutworm, Peridroma saucia (Hübner). This insect is a sporadic pest of conifer seedlings, and has been detected damaging Douglas-fir seedlings in nurseries in British Columbia (Sutherland et al. 1989).

\section{Sucking insects}

Sucking insects of the genus Lygus Hahn (Hemiptera: Miridae) can injure tree seedlings by piercing the needles to secrete digestive enzymes in order to liquefy cell content for food (South 1991). Attacks by these insects produce chlorosis of the needles, twisting and stunting of shoots, and the formation of multiple leaders that leads to stem defects, as a result of damaged apical buds (Sutherland et al. 1989; South 1991; Scarr et al. 2001). Emerging needles from injured buds will also show signs of insect damage and will grow shorter and thicker, with some seedlings exhibiting brown lesions on the main stem (South 1991). In Canada, Lygus bugs have been reported on seedlings of: jack pine, red pine, lodgepole pine, and white pine; white spruce, black spruce, and 
Norway spruce (Picea abies (Linnaeus) Karsten); and Douglas-fir (Shrimpton 1985; Scarr et al. 2001). One important species in Canada is the tarnished plant bug, Lygus lineolaris (Palisot de Beauvois). This insect occurs throughout Canada, from British Columbia to Newfoundland and Labrador (Kelton 1975). In 1983, it caused noticeable damage in several nurseries in British Columbia, attacking up to $20 \%$ of both container and bare-root stock (Shrimpton 1985). Given its wide distribution, it has been speculated to be responsible for abnormal bud development at other Canadian nurseries (South 1991).

\section{Shoot and tip insects}

A number of insect species, especially in the orders Coleoptera and Lepidoptera, infest shoots and terminal buds of trees, consuming mostly meristematic tissues of their hosts. They seldom kill the trees, but their damage to the buds and lateral and terminal branches alters the shape and growth rate of the tree, resulting in deformity, multiple branching and growth loss (Ciesla 2011). The two groups of insects of major concern are: bud and shoot-feeding moths, and the terminal and shoot weevils (Coulson and Witter 1984).

\section{Shoot and bud-feeding insects}

Twenty-four known species of Rhyacionia Hübner (Lepidoptera: Tortricidae) occur throughout the range of pines in North America, and many damage the shoots of conifers, especially pines (Coulson and Witter 1984). First instars usually mine needles and later instars feed on the buds and growing shoots of young pines, especially in plantations, even-aged natural stands, and ornamental trees (Furniss and Carolin 1977; Knight and Heikkenen 1980). As a result of the destruction of terminal bud and shoots trees are deformed, have fewer branches than unaffected trees (one or more lateral buds killed), and their foliage may lose its colour. While the growth of young pines is retarded, trees are seldom killed (Furniss and Carolin 1977; Knight and Heikkenen 1980; Coulson and Witter 1984). Young trees (up to $7.5 \mathrm{~m}$ in height), and seedlings, are more susceptible to injury by Rhyacionia species (Furniss and Carolin 1977), but they may recover from their injuries and resume normal growth when feeding is terminated (Coulson and Witter 1984).
The most important member of this genus in Canada is the non-native European pine shoot moth Rhyacionia buoliana (Denis and Schiffermueller). This moth was first detected in 1925 in Ontario, Nova Scotia, and British Columbia (Syme et al. 1995). The needle-mining larvae cause browning of the foliage, but this apparently has little effect on host vigour. Feeding on the terminal bud causes serious injury to the main stem, which affects its form. Repeated destruction of the terminal bud during the summer months initially causes profusion of shoot growth (witch's broom) and, eventually, a new spike top form when the leader dies. Various degrees of crookedness will result as the lateral branches or buds assume dominance over the terminal shoots. Attacks usually become less intensive as the trees increase in height (Syme 1984). In eastern Canada, red pine is the most seriously damaged species, whereas ponderosa pine ( $P$. ponderosa Lawson and Lawson (Pinaceae)) and the exotic species Scots pine, Austrian pine, and mugo pine are moderately susceptible. In western Canada, European pine shoot moth is a serious pest of lodgepole and ponderosa pines (Syme 1984; Syme et al. 1995). The first recorded outbreak occurred in 1938, when this insect attacked lodgepole pine in Vancouver, British Columbia (Syme et al. 1995). In Ontario, this insect has caused serious damage to red pine plantations (Pointing 1961), whereas in Québec it has been detected almost exclusively on mugo pine (Béique 1960). During the 1970s, this moth became a major pest of red and Scots pine plantations in Nova Scotia and Prince Edward Island, where up to $80 \%$ of tree buds were destroyed (Magasi 1995).

European pine shoot moth infestations were suppressed in most of eastern Canada by extremely cold winters at the beginning of the 1980s, but low level populations persisted causing sporadic damage to pine plantations (Magasi 1995). After discounting the possibility that this moth could spread to native pine plantations in British Columbia, interest in this insect declined there until 1999, when $R$. buoliana larvae were detected in lodgepole pines of the Vernon Seed Orchard Company (Okanagan Valley, British Columbia, Canada) (Heeley et al. 2003). However, Heeley et al. (2003) found no evidence of a serious threat to natural lodgepole pine stands from this pest at this time. 
The pine tip moth, $R$. adana (Heinrich), is the other member of the genus Rhyacionia that has caused severe damage to pine plantations in Canada. This moth is native to North America and its larvae feed on young red, jack, and Scots pines, usually $<1 \mathrm{~m}$ in height in nurseries, plantations, and natural stands. It will also attack the lower crowns of older trees up to $8 \mathrm{~m}$ in height (Martin 1960; Drooz 1985).

Other important shoot moths are in the genus Eucosma Hübner (Lepidoptera: Tortricidae), especially the western pine shoot borer, Eucosma sonomana (Kearfott), and the eastern pine shoot borer, Eucosma gloriola (Heinrich) (Syme et al. 1995). The former occurs in British Columbia where it feeds on its main host, ponderosa pine. Lodgepole pine, and Engelmann spruce, Picea engelmannii Parry ex Engelmann, are also attacked (Furniss and Carolin 1977). The larvae mine downward through the centre of the terminal shoots, usually reducing shoot and needle elongation, thereby stunting and sometimes killing the shoot (Furniss and Carolin 1977; Thier and Marsden 1990). Reduced tree height and a deformed crown result from repeated borer attacks (Stoszek 1973). This insect has not been considered a significant pest in British Columbia even though it had been detected infesting 36-75\% of lodgepole pines near Cascade, British Columbia, during the 1960s (Syme et al. 1995).

The eastern pine shoot borer occurs in Manitoba, Ontario, and Québec. Its main host is eastern white pine but it also feeds on jack, Scots, red, Austrian, and mugo pines (DeBoo et al. 1971). Feeding by late instars on the terminal shoots causes loss of turgidity and internal structural support, which may result in bending or breaking, whereas damaged lateral shoots lose colour and gradually die as the season advances (DeBoo et al. 1971; Drooz 1985). Infested trees become bushy after repeated attacks (Drooz 1985). In Ontario, leader damage caused by this insect was detected in $>50 \%$ of jack pine trees $<6 \mathrm{~m}$ in height, but damage occurred on about $12 \%$ of trees higher than $6 \mathrm{~m}$, suggesting that the overall incidence of this insect was low. In white pine, however, between $8 \%$ and $27 \%$ of plantations in Ontario were infested and resulted in significant loss of height growth and the deformity of the main stem, especially in trees 2-6 m tall (de Groot et al. 2003).
Another group of insect that have caused economic damage in Canada is in the genus Petrova Heinrich (Lepidoptera: Tortricidae), the Pitch-blister moths. In Canada, five species of pitch-blister moths are present, being the two most important the northern pitch twig moth, $P$. albicapitana (Busck), and the metallic pitch nodule moth, P. metallica (Busck). The former moth occurs from Nova Scotia to British Columbia and attacks jack pine, lodgepole pine, and scots pine whereas the latter moth is distributed from Saskatchewan to British Columbia and attacks lodgepole pine (Wong et al. 1995). Larvae of both species feed on the new and old growth of stem and branches of pines, causing branch deformity and breakage by wind and snow. The larvae form round nodules by combining pitch exuding from canals punctured during feeding with silk and frass where the overwinter (Martineau 1984; Wong et al. 1985). Larvae of northern pitch twig moth frequently girdle and kill the stem or the branch while feeding beneath bark whereas damage to growing terminal shoots often causes the terminal shoot to grow in a crooked manner (Turnock 1953). Larvae of metallic pitch nodule moth do not girdle the cortical tissue, but tunnel in the xylem and pith, weakening the affected area that is subjected to wind or snow breakage (Wong et al. 1995).

In Alberta, the northern pitch twig moth was highly abundant in nursery-grown lodgepole pine $0.3-2.0 \mathrm{~m}$ tall, weakening and occasionally girdling the stems that were more susceptible to wind breakage (Drouin and Kusch 1981). In 1989, surveys conducted in the province reported that between $5.8 \%$ and $12.5 \%$ of pine host showed signs of damage produced by the moth (Moody 1992). In Québec, this insect was not considered important before 1959 when outbreaks in plantations of jack pine were detected (Martineau 1984). In 1966, it was detected in several five-years-old to 10 -years-old jack pine plantations, damaging $50 \%$ or more of the trees. The infestation level remained high up to 1972 when significant damage was observed all trees in certain plantations. In 1968, the moth was also found attacking natural jack pine forest, even in mature stands (McLeod and Tostowaryk 1971). From 1973, the population level of this insect was low until 1982 when increases in insect damage were observed in certain 12-year-old jack pine populations in Portneuf, Ville de Québec and Montmorency area 
(Lachance et al. 1991). Since then, reports of northern pitch twig moth were frequent but caused low damage (Moody 1992). Occasional outbreaks of this moth have also been reported in the Maritimes Provinces (Martineau 1984; Moody 1992) whereas low incidence of this insect on regeneration has been reported in Manitoba (Emond and Still 1974) and Saskatchewan (Petty et al. 1974). As for the metallic pitch nodule moth, its nodules are observed on trees from 0.3 to $25.0 \mathrm{~m}$ tall, being the most severe observed at $3 \mathrm{~m}$ high (Wong et al. 1995). This moth has been detected attacking lodgepole pines in Alberta. However, it occurs at low level in all age classes of every forest (between $0.2 \%$ and $3.1 \%$ of trees attack) (Amirault and Pope 1989). Low population levels of this moth have also been observed in lodgpole pine stands in Saskatchewan (Cerezke et al. 1989).

\section{Terminal and shoot weevils (Coleoptera: Curculionidae)}

Weevils of the genera Pissodes Germar, Cylindrocopturus Heller, and Magdalis Germar (Coleoptera: Curculionidae) damage the terminals of young conifers, but Pissodes is the most important pest (Furniss and Carolin 1977; Coulson and Witter 1984). Weevil larvae feed on terminal tissues producing unacceptable growth losses in young stands, together with crooking or branching of the trunks (Alfaro 1989; Retnakaran and Harris 1995). Although weevil damage does not cause mortality of large trees, individuals that are $<1 \mathrm{~m}$ in height may be killed. Timber volume and quality can be reduced through the production of cross-grained wood, larger knots, and compression wood (Coulson and Witter 1984). The two most important terminal weevil species in Canada are the white pine weevil and the lodgepole terminal weevil, Pissodes terminalis (Hopping) (Retnakaran and Harris 1995). These species are similar in appearance but they differ in their life histories, behaviour, hosts, and the damage that they incur (Drouin et al. 1963).

Despite its name, the white pine weevil attacks at least 20 species of pine and spruce in Canada (Furniss and Carolin 1977). It occurs naturally across Canada, feeding upon white pine, Scots pine, jack pine, Norway spruce, and white spruce in the east (Nealis 1998), and on Sitka spruce,
Engelmann spruce, and white spruce in the western part of its range (Wallace and Sullivan 1985). Adults overwinter in the duff near the base of trees and emerge in spring. Female weevils make feeding punctures with their snouts and later lay eggs in these punctures, which are then plugged with macerated phloem. Oviposition occurs in the cambium in the top half of the previous year's leader. The larvae kill the leader by mining and consuming its phloem. Larvae pupate in chip cocoons under the bark. Newly developed adults start emerging in late summer and, before hibernation, feed on leaders of young trees (Silver 1968). Weevil attack results in the death of the terminal leader, causing one or more lateral branches to assume dominance. Fast growing trees, on good sites, are able to develop a new leader in one year. In the process of recovery, branches below the damaged terminal compete for dominance and the tree remains for one or more years with multiple leaders, thus increasing food supply for future weevil generations. The attack results in major defects (crooks and forks) in the main stem (Alfaro 1989). Repeated leader death can cause severe deformation of the main stem, rendering the tree non-merchantable. The weevil prefers vigorous trees, 2-6 $\mathrm{m}$ tall, with terminal shoots $>4 \mathrm{~mm}$ in diameter (Gross 1985). Although this weevil typically does not directly cause tree mortality, the stunted growth of susceptible trees - usually the most vigorous trees in the stand -may result in them being eliminated from the site by competing vegetation (Alfaro 1982).

White pine weevil causes severe problems to reforestation programmes throughout Canada. In Québec, Norway spruce and white pine are the most affected species. In 1999, $90 \%$ and $85 \%$ of Norway spruce and white pine plantations, respectively, were attacked in some regions of the province (Boucher et al. 2001). In 2011, only 16\% and $18 \%$ of trees in the respective plantations of these species were attacked at the provincial level (Ministère des Ressources naturelles et de la Faune 2012). In Ontario, white pine is the species most damaged by this weevil, followed by jack pine and Norway spruce (Scarr et al. 2001). A survey of Ontario white pine plantations indicated that, within a given year, $50 \%$ of stands were infested with this weevil, with up to $28 \%$ of trees being attacked (Gross 1985). In coastal 
British Columbia, Sitka spruce had been so severely damaged that planting of this species, a valuable timber tree, was not recommended in most harvested areas (Alfaro et al. 1995). However, a breeding programme in British Columbia succeeded in identifying tree genotypes with heritable and stable resistance against this weevil in Sitka and white spruce, allowing the establishment of operational seed orchards. Currently, the availability of resistant seed is contributing to increase the productivity of white spruce in the interior of British Columbia and has allowed the return of Sitka spruce as a timber species of choice in coastal British Columbia (Alfaro et al. 2013).

Lodgepole terminal weevil is distributed from Manitoba to British Columbia, and mainly infests the terminal leaders of lodgepole and jack pine (Drouin et al. 1963; Langor and Williams 1998). Unlike white pine weevil, the lodgepole terminal weevil attacks current growth, with feeding damage being concentrated above the nodal branches and intermodal shoots as the larvae move up the stem (Drouin et al. 1963). Attacks by lodgepole terminal weevil and white pine weevil kill the terminal leader, resulting in crooking or branching of stems (Drouin et al. 1963; Maclauchlan and Borden 1996). Although it has not been completely assessed, the effect of the lodgepole terminal weevil on regenerating pine stands is undoubtedly less severe than that caused to spruce and pines by the closely related white pine weevil (Langor and Williams 1998). In British Columbia, $40 \%$ and $50 \%$ top-kill was reported in two stands (Amman and Safranyik 1984). Maclauchlan and Borden (1996) reported that height loss due to $P$. terminalis attack was $31.4 \%$ of the annual potential height increment in the year of attack, and $17 \%$ in the year following attack. In 2011, plot re-measurement revealed that the $P$. terminalis infestation increased by $27 \%$, but its effects on tree growth and shape had decreased substantially since 2002 (Westfall and Ebata 2011). From 1982 to 1985, the cumulative incidence of this weevil in Alberta was as high as $87 \%$ in lodgepole stands and around $32 \%$ in jack pine stands in Saskatchewan (Langor et al. 1992).

Other weevils can attack the terminal leaders and branches of pines, including Cylindrocopturus species and the defoliating weevil Magdalis gentilis (LeConte) (Coleoptera: Curculionidae). These weevils cause damage similar to that incurred by lodgepole terminal weevil (Kovacs and McLean 1990), but their effects are not considered important because populations are never very high (Furniss and Carolin 1977).

\section{Gall insects}

Many kinds of insects cause galls on forest trees. These insects inject a chemical substance into the plant that causes it to grow abnormally and produce a gall (Coulson and Witter 1984). Thus, gall-formers have the ability to manipulate the growth and development of plant tissues (Dreger-Jauffret and Shorthouse 1992). Chemical compounds that stimulate gall formation are usually provided by the feeding stage of the insect, but the ovipositing female of some species injects the compounds when she lays eggs on the plant (Coulson and Witter 1984). The changes in cell structure are thought to improve the nutritional value of the attacked plant part for the insect, reduce chemical defenses, and provide shelter (Price et al. 1987). If the insect dies or leaves the host, the plant resumes normal growth (Coulson and Witter 1984). Galls can be found in all parts of a tree, from the foliage to the roots (Furniss and Carolin 1977; Coulson and Witter 1984). They are caused by insects in the orders Thysanoptera, Hemiptera, Lepidoptera, Coleoptera, Diptera, and Hymenoptera (DregerJauffret and Shorthouse 1992). Gall insects are not considered economically important in forest stands, but they can inflict severe damage to ornamental trees, shrubs, nurseries, and young stands (Coulson and Witter 1984). The most problematic gall insects in Canada are the gall and pitch midges (Diptera: Cecidomyiidae), and the gall adelgids (Hemiptera: Adelgidae) (Humble and West 1995).

Gall and pitch midges. The spruce bud midge, Dasineura swainei (Felt) (Diptera: Cecidomyiidae), occurs throughout the boreal region of Canada and attacks red spruce, Picea rubens Sargent (Pinaceae); Colorado blue spruce, P. pungens Engelmann (Pinaceae); as well as black, white, and Norway spruces (Clark 1952; Cerezke 1972). At the end of spring, newly hatched larvae bore into shoot tips, which leads to gall formation (West 1989). Larvae feed within galled buds throughout the summer and mature at the end of autumn. Larvae overwinter in buds and transform 
into pupae in late April to early May. Adults emerge three weeks later, with the females ovipositing in flushing shoots in the late spring (Humble and West 1995). When the terminal leader bud is damaged, subordinate buds compete for dominance and eventually one becomes the new leader or dominant shoot. Reductions in height growth of about $25 \%$ and $16 \%$ have been observed in white and black spruce, respectively, as a result of attacks by spruce bud midge (Cerezke 1972; West 1989). However, the effects of this insect are considered to be rather minor. For example, $<4 \%$ of shoots in white pine plantations in the Maritime provinces were attacked by this midge in 1982 (Magasi 1983). Cozens (1985) reported that spruce bud midge had attacked $2.2 \%$ of all spruce stems in plantations in Prince George, British Columbia. In Saskatchewan, this insect attacked $3.9 \%$ of all stems in young stands of white spruce (Cerezke and Brandt 1993). Higher levels of infestation $(28 \%)$ and attack $(13 \%)$ by the midge were observed in Québec spruce plantations in 2011 (Ministère des Ressources naturelles et de la Faune 2012).

Balsam gall midge, Paradiplosis tumifex Gagné (Diptera: Cecidomyiidae), forms $\sim 3$-mm-diameter galls at the base of the needles on mature and immature balsam fir, which is its main host. In Canada, the midge is found throughout the range of balsam fir, but it has also been observed attacking Fraser fir, Abies fraseri (Pursh) Poiret (Pinaceae), in British Columbia as well (Martineau 1984; Drooz 1985; Humble and West 1995). After hatching, the larvae move to the bases of the needles to find a suitable feeding site. By late July, the gall is fully developed at the larval feeding site. At maturity, larvae leave the galls to overwinter in the duff or mineral soil (West and Shorthouse 1982; Humble and West 1995). Galled needles gradually turn yellow and drop from the twigs in October (Drooz 1985; Humble and West 1995). Since balsam gall midge damage is more serious in young balsam fir trees ( $<8 \mathrm{~m}$ tall) than it is in older and taller trees, this pest is of major concern in young plantations and Christmas tree plantations (Drooz 1985; Ives and Wong 1988). Outbreaks of balsam gall midge have occurred in the Maritimes, Ontario, and Québec since 1938. Until the 1960s, outbreaks in the Maritimes and Ontario were severe. Since then midge population densities have remained relatively low, with occasionally localised outbreaks. For example, only one balsam fir plantation exhibited $>20 \%$ needle infestation in the Maritime Provinces (Kondo and Moody 1987). Québec outbreaks, in contrast, have been localised, lasting a few years (Humble and West 1995). A localised outbreak lasting three years occurred in Québec in 2000 , causing $60 \%$ of buds infested in one balsam fir Christmas tree plantation (Cloutier et al. 2006).

The jack pine resin midge, Cecidomyia resinicola (Osten Sacken) (Diptera: Cecidomyiidae), ranges from British Columbia to Québec. Since 1963, jack pine resin midge outbreaks have occurred in jack pine plantations in south-central Ontario and central Québec, and in natural stands in western Québec (Martineau 1984). This insect has also been reported causing moderate damage in jack pine plantations in localised areas near Grand Rapids, Manitoba (Kondo and Moody 1987). It also attacks pitch pine, and lodgepole pine (Gagné 1978; Ives and Wong 1988). Adults emerge in late May or early June. Eggs are laid singly on the bark or needles of the new shoots, but usually on shoots that are only lightly resinous. The eggs hatch within about six days, and the young larvae burrow into pitch masses that accumulate on the new shoots. The larvae feed on the resin, as their mouthparts are not suited to rasping the tissues of the host. This feeding appears to irritate the young tissue and stimulates the flow of pitch until it forms a mass, in which the partially developed larvae can overwinter. Pupation occurs within the pitch masses, but the pupae wriggle out of the pitch before adult emergence (Martineau 1984; Ives and Wong 1988).

Height growth reductions and rarely mortality can result from jack pine resin midge attacks. Although this midge can attack and destroy the shoots of older trees that grow on poor sites, its feeding causes greater damage to young pines and can kill up to $75 \%$ of the affected shoots (Martineau 1984). Yet, infestations are rarely severe enough to affect radial increment or cause mortality (Martineau 1984; Ives and Wong 1988). In 2011, $29 \%$ of jack pine plantations in Québec were attacked by this midge, but the level of damage was low (Ministère des Ressources naturelles et de la Faune 2012).

Other midges that can cause minor damage on young stands in Canada are the jack pine 
midge, Cecidomyia piniinopis (Osten Sacken); the European pine needle midge, Contarinia baeri (Prell); the red pine midge Thecodiplosis piniresinosae (Kearby); other Contarinia Rondani species; the spruce gall midge, Mayetiola piceae (Felt); the false balsam gall midge, Dasineura balsamicola (Lintner); and Chamaediplosis nootkatensis Gagné and Duncan (Humble and West 1995).

Gall adelgids. Adelgidae (Hemiptera) feed exclusively on conifers. This family contains two genera, Adelges Vallot and Pineus Shimer. In North America, the most important species within the family are the eastern spruce gall adelgid Adelges abietis (Linnaeus) (Hemiptera: Adelgidae) and the cooley spruce gall adelgid, A. cooleyi (Gillette) (Coulson and Witter 1984; Harris and Bowers 1995). Adelges abietis is found throughout Canada, mainly on Norway and white spruce, but Colorado, blue, and red spruces are also occasionally affected (Friend and Wilford 1933; Martineau 1984). The spruce gall adelgid is bivoltine (i.e., completes two generations per year). In the spring, after overwintering at the base of the buds, the nymphs become adults and females lay eggs on spruce needles. After hatching, the nymphs feed at the base of the needles and form pineapple-shaped galls on developing shoots of spruce trees in the spring (Coulson and Witter 1984; Martineau 1984). The presence of galls reduces the aesthetic value of ornamentals and Christmas trees, and can reduce tree growth in plantations when adelgid populations are high (Friend and Wilford 1933; Coulson and Witter 1984). The adelgid is not common in the Maritimes or Newfoundland and Labrador, but it has wreaked considerable damage in Québec and Ontario, most noticeably in the southern regions of both provinces (Martineau 1984). In 1982, the infestation rate of this insect in the Maritime Provinces was $<1 \%$ of shoots, except for two New Brunswick sites and one site in Nova Scotia where $3 \%$ and $1 \%$ of shoots were affected, respectively (Magasi 1983). In 2011, 32\% of spruce plantations in Québec showed signs of eastern spruce gall adelgid attack. The damage, however, was low in most plantations (Ministère des Ressources naturelles et de la Faune 2012).

The Cooley spruce gall adelgid occurs across Canada, but it is more abundant in the west where its alternate host, Douglas-fir, is present. The most seriously affected tree species are white spruce, Engelmann spruce, and Douglas-fir, but this insect will occasionally attack interior spruce, Picea engelmannii Parry $\times P$. glauca (Moench) Voss, as well as black, red, and Sitka spruce. The Cooley spruce gall adelgid is indigenous to North America (Cumming 1959; Martineau 1984) and has natural history similar to that of the eastern spruce gall adelgid. In the west, however, it alternates between spruce and Douglas-fir, and goes through several generations annually on each host (Cumming 1959; Coulson and Witter 1984). The complete life cycle takes two years, including alternation of generations between hosts (Cumming 1959), but a shorter life cycle has been detected in Alberta and Saskatchewan (Cumming 1962). The elongate and pineapple-shaped gall of this insect may cover the entire length of the shoot or only one side, which can bend the shoot. Galls are not formed in Douglas-fir, but its needles will turn yellow and drop off (Martineau 1984). In natural forests, its damage is not serious except on seedlings and young trees, where the galls will kill the tips of branches, as well as stunt and deform the trees when they occur on the main stem (Furniss and Carolin 1977). Damage can reduce the aesthetic value of ornamentals and Christmas trees, and reduces tree growth in plantations when insect populations are high (Coulson and Witter 1984; Martineau 1984). This adelgid is commonly observed throughout northern and western Alberta, and in northwest Saskatchewan, but its impacts have been considered low (Cerezke and Brandt 1993). In British Columbia, high infestation rates have been reported in some interior spruce plantations (up to $100 \%$ ), but the insect rarely threatened tree health (Simard and Hannam 2000). The spruce gall adelgid, Adelges lariciatus (Patch), is native to North America and is distributed from the Maritimes provinces to British Columbia (Cumming 1968; Rose and Lindquist 1994; British Columbia Ministry of Forests and Range 2009). This adelgid has been recorded in white spruce, black spruce, blue spruce, tamarack, subalpine larch (Larix lyallii (Parlatore)), and Siberian larch (Larix sibirica Ledebour). It alternates between spruce and larch and typically goes through six generations annually (Cumming 1968). This insect produces pineapple-shaped galls that cause a marked reduction of needle length on the galls (Ives and Wong 1988) and 
damage and destroy current or future cones sites (British Columbia Ministry of Forests and Range 2009). This insect is considered of minor economic impact because it rarely affects the health of its hosts (Martineau 1984; British Columbia Ministry of Forests and Range 2009) but heavy gall formation can stunt or kill twigs, which can disfigure valuable trees. For example, high populations of this insect were detected on planted white spruce grown for genetic tree improvement and on shelterbelt trees within nurseries in Alberta in 1986 (Cerezke et al. 2011). Although there is no evidence that this adelgid seriously affect seed production, it can make difficult seed extraction due to excessively gummed cones (Bennet 1994).

\section{Defoliating insects}

Foliage of young trees serves as the principal food source for a great number of folivorous insects from five orders: Coleoptera, Diptera, Hymenoptera, Lepidoptera, and Orthoptera. (Furniss and Carolin 1977; Coulson and Witter 1984). Defoliation affects the tree by reducing its photosynthetic surface, and by interfering with transpiration and the processes of photosynthate translocation within the tree (Coulson and Witter 1984). The impacts of defoliators can be very serious, depending on their population densities. Trees can withstand defoliation without being seriously affected when the population densities are low to moderate. If population densities surpass a certain level, heavy feeding will reduce tree growth and may eventually kill the young tree, especially if it occurs in successive year and whether the feeding is confined to new or old needles. Factors such as tree species, tree age, site quality, tree health weather conditions, and secondary insects and diseases can modify insect defoliation effects by affecting tree resistance. Caterpillars of moths (Lepidoptera) and sawflies (Hymenoptera) are the most damaging insects that consume foliage (Furniss and Carolin 1977).

Lepidoptera. The spruce bud moth, Zeiraphera canadensis Mutuura and Freeman (Lepidoptera: Tortricidae), is a native defoliator of spruce in North America, and occurs throughout Canada on its preferred host, white spruce (Mutuura and Freeman 1966). The bud moth is also found on black spruce, Sitka spruce, balsam fir, and other species of conifers (Drooz 1985). The female looks for small spruce trees about $2 \mathrm{~m}$ in height upon which to oviposit. From mid July to late July, she oviposits on the scales at the base of current-year shoots, and diapausing eggs overwinter (Turgeon 1985). Egg hatch usually occurs in May and is well synchronised with budburst (Turgeon 1986; Quiring 1993), because the temporal window for bud colonisation is only four to five days long (Quiring 1992). First instars colonise newly burst buds (Quiring 1993). After completing development, the fourth instars drop to the ground and pupate in the litter (Turgeon 1985). Adult eclosion starts about three weeks later, with a flight period usually lasting two to three weeks (Turgeon et al. 1995). The damage is caused by third instars and fourth instars, which feed on the cortical tissues of growing shoots and frequently destroy them, resulting in the production of multiple leaders, reduction in growth, and stem deformity. Carroll et al. (1993) reported that spruce bud moth caused immediate and substantial reductions in height increment, but volume increment was not affected unless white spruce sustained two to three consecutive years of heavy damage. Quiring (1993) observed that 15-year-old white spruce trees that had sustained continual attack had more than five leaders, were $<2 \mathrm{~m}$ in height, and had been "overtopped" by undamaged conspecifics of the same age.

This moth had been considered of minor economic importance until 1980, when it infested $>16000$ ha of white spruce plantations in New Brunswick, causing shoot distortion and tree deformation. Since then, it has become widespread throughout the Maritime provinces, attaining shoot damage levels as high as $96 \%$ in New Brunswick, 55\% in Nova Scotia, and 70\% in Prince Edward Island in 1985 (Magasi 1995). In 1991, the bud moth caused severe defoliation of white and black spruce stands in Newfoundland and Labrador (Raske et al. 1992). In the early 1980s, it caused considerable damage to white pine plantations of the Lower St. Lawrence-Gaspé Peninsula of Québec, and by 1987, it was present in $88 \%$ of white pine plantations causing $32 \%$ terminal shoot damage (Lachance 1995). Spruce bud moth infestations decreased considerably in Québec during the 1990s; provincial monitoring of spruce bud moth populations in white spruce plantations was discontinued in 1999 (Ministère des Ressources naturelles 2000). No severe 
damage caused by this moth has been detected in Ontario, probably because plantations of its main host, white spruce, are not common in this province (Scarr et al. 2001).

The genus Choristoneura Lederer (Lepidoptera: Torticidae) includes several important defoliators that cause serious damage, mainly to mature forests, but they can also damage young stands (see Nealis 2015 in this special issue for further information on genus Choristoneura). The most notorious member of this genus is the spruce budworm Choristoneura fumiferana (Clemens). This insect occurs throughout Canada, where it feeds preferably on balsam fir, followed by white spruce, red spruce, and black spruce. This budworm is the most destructive insect pest in the maritime and boreal forests of North America. Populations of this forest defoliator have reached outbreak densities over extensive forested areas on a fairly regular basis over the past three centuries, at the very least (Blais 1965; Burleigh et al. 2002). Mature stands of balsam fir are the most vulnerable to spruce budworm (MacLean 1980), but this insect also attacks young stands, although it rarely causes mortality until the stands are over 20 or 25-year-old (Scarr et al. 2001). During the 1970s-1980s outbreak in eastern Canada, spruce budworm defoliation not only affected mature trees, but also naturally regenerated and plantation forests. After two years of severe defoliation, young balsam fir sustained a $50 \%$ reduction in volume growth (Piene 1980), whereas young white spruce exhibited a $27 \%$ reduction in volume growth (Piene 1991).

The western spruce budworm, Choristoneura occidentalis (Freeman), is a major pest of Douglas-fir, grand fir, subalpine fir (Abies lasiocarpa (Hooker) Nuttall), Engelmann spruce, white spruce, and western larch (Larix occidentalis Nuttall), in western Canada and the United States of America, with Douglas-fir being the most damaged species (Coulson and Witter 1984). Similar to other members of this genus, the western spruce budworm periodically reaches outbreak levels throughout its range (Alfaro et al. 2014). Budworm defoliation causes tree mortality, reduction of growth rates, dieback, and reduced lumber quality. Young stands are the most vulnerable to damage; dead tops on young trees can result in future stem deformities (Heppner and Turner 2006). Mortality is more prevalent among trees in the lower canopy and understorey regeneration than in the dominant or co-dominant strata (Alfaro et al. 1982; Alfaro 1986). If the understorey regeneration is lost to budworm in forests managed in shelterwood silvicultural systems, the mature trees cannot be removed until a new understorey becomes established, which creates regeneration delays (Alfaro 1991). A recent outbreaks of western spruce budworm occurred in Alberta between 2000 and 2012 when budworm populations in southwest Alberta collapsed. The outbreak reached its peak in terms of area in 2008 when over 30779 ha of Douglas-fir stands were attacked. It was, however, in 2007 when the impact of this outbreak was greater because severe defoliation was observed in over 16201 ha in Porcupine Hills (Environment and Sustainable Resource Development Alberta 2008, 2010, 2013).

The jack pine budworm, Choristoneura pinus Freeman, feeds mainly on jack pine foliage, but it can also consume red pine, white pine, and Scots pine, especially when these species are minor components of jack pine stands (Howse and Meating 1995). This budworm occurs from New Brunswick to British Columbia, but has caused the most damage in Ontario, Manitoba, and Saskatchewan (Martineau 1984). Outbreaks of this defoliator typically occur at 6-year to 12-year intervals and persist for two to three years (Volney 1988). Jack pine budworm attack can result in growth loss, reduced seed production, top kill, and tree mortality (Howse and Meating 1995). Usually, the most severe damage is found in overstocked, overmature stands (Coulson and Witter 1984), but this insect can also damage young stand and plantations. Young stands are immune to jack pine budworm attack until they start to flower, which probably occurs for the first time when they are 20 years old (Volney 1988). High densities of this defoliator may be found in plantations younger than 40 years old, but tree mortality is rather low (Scarr et al. 2001).

Hymenoptera. Sawflies are one of the most destructive groups of insects in young conifer stands. They receive their name from the sawlike ovipositor of the female. The most destructive sawflies belong to the families Diprionidae and Tenthredinidae. Diprionid sawflies feed mainly on pines, whereas tenthredinid sawflies feed on spruce, fir, larch, and hardwoods (Coulson and 
Witter 1984). Sawflies are often present in plantations at low population levels but can occasionally increase to levels that cause significant damage.

The redheaded pine sawfly, Neodiprion lecontei (Fitch) (Hymenoptera: Diprionidae), is one of the most damaging insects that attack young pine plantations in Ontario, Québec and, to a lesser extent, in New Brunswick, Nova Scotia, and Prince Edward Island (Wallace and Cunningham 1995). The redheaded pine sawfly produces one generation per year in Canada, whereas it may have as many as five generations farther south (Benjamin 1955). In Canada, adult sawflies emerge from mid-June to early July. The emerging larvae are gregarious and preferentially feed on previous year's foliage and overwinter in the soil. Red pine is the principal host, but can include jack pine and Scots pine. Damage can be severe, especially on trees less than two to three years old (Cunningham and de Groot 1984). This sawfly is a voracious feeder that readily strips small trees (1-5 $\mathrm{m}$ tall) of part or all of their foliage. Young trees may be deformed or killed during an outbreak, which can last two to three years (Averill et al. 1982). In Québec, the last outbreak occurred from 1974 to 1978 in red pine plantations (Martineau 1984; Lachance 1995). Since then, it has been present at endemic levels until 1999, when it caused increased damage. No serious damage, however, has been observed since this sawfly population was controlled using a nuclear polyhedrosis virus (Ministère des Ressources naturelles 2000). In Ontario, redheaded pine sawfly populations have fluctuated since the last outbreak was detected in 1974 (Martineau 1984; Howse 1995) but caused 33\% mortality at one site in 1981 (Howse 1995). In southern Ontario, heavy sawfly damage was recorded in young $1-\mathrm{m}$ tall red pine plantations in 1996 (Ingram et al. 1997) and 80\% infestation levels in one plantation of 4-m tall red pine in 2002 (Evans et al. 2002)

The yellowheaded spruce sawfly, Pikonema alaskensis (Rohwer), (Hymenoptera: Tenthredinidae) is a pest of young, open-grown spruces across Canada (Martineau 1984). Although it has been reported to attack several spruce species (Ives and Wong 1988; de Groot 1995), this sawfly is particularly harmful to plantations of black spruce and white spruce (Hall et al. 1998). It can be found in nurseries, cutover areas, and in young natural regeneration (Martineau 1984). Larvae feed mainly on current-year foliage, although older age classes may be eaten if new foliage becomes sparse (Johns and Quiring 2010). This insect causes serious defoliation, growth reduction, and tree mortality, especially since this sawfly tends to concentrate its attacks on trees previously defoliated (Ives and Wong 1988; Katovich et al. 1995). In 1995, moderate-tosevere defoliation by this sawfly was reported in black and white spruce plantations in Newfoundland and Labrador, New Brunswick, Prince Edward Island, and Ontario. Only low-level infestations were observed in Nova Scotia and Québec (Hall et al. 1998). In 2011, defoliation by this insect in Ontario was localised to some districts and mainly affected trees $<3-\mathrm{m}$ tall. These individuals exhibited up to $50 \%$ defoliation (Scarr et al. 2012). This sawfly was observed in $13 \%$ of spruce plantations in Québec, but signs of attack were evident in $10 \%$ of the trees (Ministère des Ressources naturelles et de la Faune 2012).

The balsam fir sawfly, Neodiprion abietis (Harris), occurs from coast to coast in southern Canada (Drooz 1985), where its preferred host is balsam fir. This sawfly also feeds on white spruce, black spruce, and, less frequently, red spruce (Martineau 1984). Larvae hatch in late June to early July, and feed first on one-year-old foliage, but later continue to feed on the remaining foliage, except the current-year needles (Piene et al. 2001). Damage may result in reduced vigour and growth, and tree mortality. Outbreaks of this sawfly have historically been of short duration and have been observed from Saskatchewan eastward (Cunningham 1984; Martineau 1984). However, the current outbreak in western Newfoundland, which began in 1991, is unprecedented in severity and duration, having affected young managed stands of balsam fir (Piene et al. 2001; Moreau 2006). During 1991-2011, a cumulative area of 582790 ha was moderately-to-severely defoliated in Newfoundland (Canadian Council of Forest Ministers 2013). In New Brunswick, balsam fir sawfly was detected over a 181800 ha area in 2010; of which 7282 ha of crown forest was aerially sprayed with the biological insecticide Abietiv $^{\mathrm{TM}}$ (Balsam Fir Sawfly Polyhedrovirus, Sylvar Technologies Inc., Fredericton, New Brunswick, Canada). By 2012, its population had 
collapsed and only light scattered defoliation was detected within a small geographic area (New Brunswick Department of Natural Resources Forest Pest Management Section 2013). In 1995, this insect caused moderate to high damage in Québec, while 250 ha were heavy defoliated in Nova Scotia (Hall et al. 1998). In Ontario, balsam fir exhibited up to 60\% defoliation in 1995 (Hall et al. 1998) and 20-65\% defoliation in 2011 (Scarr et al. 2012).

The larch saw fly, Pristiphora erichsonii Hartig (Hymenoptera: Tenthredinidae), occurs in all Canadian provinces (Drooz 1985). Although this sawfly is specific to larch, its preferred host in Canada is tamarack (Martineau 1984). This univoltine insect reproduces by obligatory parthenogenesis and males form only $2 \%$ of the population (Turnock 1960; Martineau 1984). Females lay their eggs in slits that they cut with their ovipositor on new shoots (Turnock 1960). The oviposition injury retards the growth on the side of the shoot containing eggs but not in the opposite side, curling the tip of the shoot (Lejeune 1947). After hatching, the larvae feed in light clusters, completely stripping the foliage (Lejeune 1947; Turnock 1960). Defoliation is concentrated in certain parts during light outbreaks but the entire crown can be defoliated during severe outbreaks (Martineau 1984). The first recorded outbreak of this insect began in the early 1880s near Ville de Québec and then it spread to Ontario, New Brunswick, and Nova Scotia, wiping out millions of ha of tamarack (Lejeune 1947; Coppel and Leius 1955; Martineau 1984). In 1938, a serious outbreak began in Manitoba and then extended to Saskatchewan and Ontario, mainly affecting young stands of tamarack (Lejeune 1947). Most tamarack stands sustained up to three consecutive years of severe defoliation, and almost $20 \%$ mortality of tamarack in several stands in Manitoba and Saskatchewan. By the mid 1960s, population levels of this insect gradually declined and remained low with minor fluctuations until 1984 when small areas of moderate to severe defoliation where observed in west-central Manitoba (Cerezke and Volney 1995). In 1957, increases in the population level of this insect were observed in western Québec and extended throughout the province during the next 10 years (Martineau 1984), causing severe defoliation in several stands of tamarack (Lachance et al. 1991).
Since 1968, this insect has been present in the province at endemic levels (Lachance 1995). From 1973 to 1975 , this insect caused very severe defoliation in the eastern part of Prince Edward Island. In Nova Scotia, most of the southern mainland and much of Cape Breton Island surface was severely defoliated in 1975. New Brunswick was also affected by this outbreak, but its impact was not as high as it was in Prince Edward Island and Nova Scotia. The outbreak collapsed in 1980 (Magasi 1995). Outbreaks of this insect in Newfoundland are very common (Hudak and Raske 1995). In 1942, dramatic population increases were recorded in two areas and persisted until 1949 when the outbreak collapsed. A second wave of population increases began in 1953 causing severe defoliation until 1968 when the outbreak collapsed due to unfavourable weather conditions (Martineau 1984). Since 1970, several larch sawfly outbreaks have persisted in Newfoundland but their impact has not been considered important because larch is currently not a commercial forest species in this province, and the tree is only a scattered component within coniferous stands (Hudak and Raske 1995).

Other sawflies that can affect young conifers in Canada are the non-native European pine sawfly, Neodiprion sertifer (Geoffroy), and European spruce sawfly, Gilpinia hercyniae (Hartig) (Hymenoptera: Diprionidae) (Wallace and Cunningham 1995). In its native range, the European pine sawfly prefers mugo and Scots pine, feeding to a lesser extent on Austrian pine. In North America, however, it feeds mainly on jack pine and red pine, but also on white pine, ponderosa pine, pitch pine, shortleaf pine (Pinus echinata Miller), and Japanese red pine (Pinus densiflora Siebold and Zuccarini). Within its native range, European spruce sawfly feeds upon Norway spruce and plantations of introduced spruces, especially in the United Kingdom (Billany et al. 1983). Introduction of this sawfly species into North America in the 1930s initially caused great losses of merchantable timber in the Gaspé of Québec, but shortly thereafter diminished in economic importance as biological control measures were implemented (Griffiths et al. 1984).

\section{Sucking insects}

The damage caused by Hemiptera with their piercing and sucking mouthparts is normally less 
apparent and damaging than that caused by other groups of insects such as defoliators; however, some species in the families Adelgidae and Aphididae can severely damage and even kill trees (Coulson and Witter 1984). Adelgids and aphids undergo incomplete metamorphosis but tend to have complex life cycles. Some have alternate hosts and others have both sexual and asexual reproductive stages with winged and wingless forms (Ciesla 2011). Feeding by these insects causes foliage discolouration, interferes with transport of photosynthate and water supplies within trees, reduces tree growth, and causes branch and tree mortality if there is severe and repeated damage over a long time (Coulson and Witter 1984). These insects are generally very small, which renders the detection of their presence difficult before damage occurs (Ciesla 2011).

One of the most damaging members of this group in Canada is the balsam woolly adelgid, Adelges piceae (Ratzeburg) (Hemiptera: Adelgidae). Native to Europe, it was first detected in eastern Canada in 1908 (Balch 1952), but now occurs in British Columbia, New Brunswick, Newfoundland and Labrador, Nova Scotia, Prince Edward Island, and Québec (Harris and Bower 1995). This adelgid is a pest of Abies, and attacks balsam fir in eastern Canada and subalpine fir, amabilis fir, and grand fir in western Canada (Martineau 1984; Harris and Bower 1995). Reproduction of this adelgid is parthenogenetic and adults are tiny (about $1 \mathrm{~mm}$ in length) and wingless. The newly hatched juveniles, or "crawlers", are the only stage capable of directed movement or dispersal. Long range spread is accomplished mainly by wind. Throughout the remainder of the life cycle, the insect is anchored to the tree by its feeding mouthparts (stylets), which are inserted in the bark feeding on phloem sap (Greenbank 1970; Martineau 1984). Trees of all sizes can be attacked by this insect, producing two forms of damage. Infestations on twigs and branches result in swelling and distortion of twigs, a condition known as "gout" (Balch 1952). This process, which takes about 25 years to complete, causes crown decline, branch dieback, and "top kill" (Martineau 1984). Severe feeding damage on the bole causes swelling of the affected area and results in restriction of water flow. During heavy adelgid infestations, trees can die in three to four years (Martineau 1984).
This adelgid caused considerable damage to balsam fir stands in Newfoundland and Labrador from the late 1950 s to early 1960 s, but its population densities decreased dramatically by the late 1960s for unknown reasons (Magasi 1995). The adelgid caused significant damage in several regions of the province in 1995, especially in stands where thinning occurred (Hall et al. 1998). In the Maritime Provinces this adelgid caused similar mortality as did spruce budworm during the 1950s and early 1960s. Since then, balsam woolly adelgid populations were reduced by cold winters until 1979, when this insect was again detected attacking trees in $11 \%$ of the forested areas of New Brunswick, 74\% in Nova Scotia, and $25 \%$ in Prince Edward Island. Despite these attacks, damage remained low and stable until 1981, when a serious infestation affected 122 ha of Christmas tree plantations in Nova Scotia (Magasi 1995). Currently, low-level attacks occur in New Brunswick, with only $\sim 0.5 \%$ of balsam fir trees showing moderate-severe damage in 2010; no significant areas of damage were observed in 2012 (New Brunswick Department of Natural Resources Forest Pest Management Section 2013). In Nova Scotia, monitoring of balsam woolly adelgid populations and damage was discontinued by 2007 (Penny 2007). In Québec, a survey revealed that about $2500 \mathrm{~km}^{2}$ were infested by this adelgid on the Gaspé, but levels of damage were low (Lachance 1995). In British Columbia, the most serious infestation occurred in 1987, when over 150 ha of amabilis fir were attacked and tree mortality reached $30 \%$ (van Sickle 1995). This adelgid seems to be present wherever fir seedlings are produced for reforestation on Vancouver Island. Tests of experimental adelgid infestations on one-year-old seedlings showed that the pest reproduced successfully after one growing season on containerised nursery stock (Hall et al. 1998).

The balsam twig aphid, Mindarus abietinus Koch (Hemiptera: Aphididae), is found throughout the range of native fir across Canada, feeding mainly on balsam fir, but also on amabilis fir, grand fir, and subalpine fir (Dawson 1971; Martineau 1984). Although it can attack natural forests, its damage is more economically important on ornamental and Christmas trees because it reduces their aesthetic value (Coulson and Witter 1984). This aphid has three or four generations per 
year, which extend from early May to early July, overwintering as diapausing eggs on tree foliage (Martineau 1984). Feeding on newly opened buds and current-year shoots results in needle distortion and shoot stunting (Furniss and Carolin 1977). In Canada, outbreaks of this insect generally develop on balsam fir, but are of short duration. In Newfoundland, this aphid has normally caused low to moderate damage to balsam fir (Raske et al. 1992; Magasi 1995), except when it caused serious damage in 1972 in the Bay d'Espoir region (Martineau 1984). In the Maritime Provinces, local and short-term outbreaks are detected every three to four years (Martineau 1984). In 2012, $13 \%$ of 281 plots in New Brunswick had detectable levels of damage attributable to this pest (New Brunswick Department of Natural Resources Forest Pest Management Section 2013). In Nova Scotia, monitoring programmes were suspended in the province, because of low incidence of the aphid from 2003 to 2006 (Penny 2007). Population densities of this aphid in Ontario have been usually low, except for an outbreak in 1946 (Martineau 1984). Infestations in British Columbia have been most frequent in open stands of immature amabilis and grand fir on Vancouver Island and in young subalpine fir stands in much of the interior, producing heavy damage (Dawson 1971). In 1978, high densities of the insect were reported with significant damage to localised areas in the province, whereas the damage was low in 1986 (van Sickle 1995). The last outbreak was reported in 1989 (Hall et al. 1998).

\section{Assessing the impacts of pests of young stands}

Assessment of the impacts of pests of young stands is a critical prerequisite to determine the levels of expenditures to be committed in management and research on these pests. Damage to the young age classes of the forest can have serious impacts on the short-term to long-term development of a forest. In the short term, losses to regeneration negate the initial investments in activities such as site preparation, plantation, and silviculture, and extensive damage can lead to plantation failure, which causes rotation delays and additional investments in restoration. In the long term, these pests reduce the total harvest and, because of selective mortality, they can change the species mixture at rotation and thus disturb the timber supply process. In forests managed in a multi-age silvicultural system, such as shelterwood systems, damage to the young age classes will result in gaps in the expected timber supply.

Assessing the impacts of damage that occur at an early age requires stand and landscape models capable of forecasting growth and yield, while separating the effects of the pest from mortality due to natural causes, such as attrition during forest development. For example, natural mortality occurs due to the natural process of stem exclusion, which takes place when stands change from open-grown to a closed canopy forest.

Modelling impacts requires good knowledge of pest epidemiology and damage, as well as of the processes of stand and landscape dynamics. Volney et al. (2005) developed a framework for assessing the risk of damage to young poplar plantations in Canada, which could be applied to other situations. Insect and diseases of poplars were categorised as annual or cyclical events, or chronic disturbances. The latter included those pests that, once established, may affect the plantation for extended periods, for example, gall aphids. The model also considered the temporal distribution of the disturbance, that is, the statistical distribution of its occurrence in time, and whether its effects would linger and affect plantation productivity for several years.

Impact models also require an understanding of how the pest causes its damage to young trees and stands, including expected levels of mortality, growth reduction, and potential trunk deformities resulting in the affected trees. In addition, these models require a description of how the stand dynamics is changed by the pest event, in the short and long term (at harvest).

This complex information can be integrated into a decision support system for pests of regenerating forests capable of estimating potential economic losses at the end of rotation, comparing yields with and without pest damage. For example, Yemshanov et al. (2011) used the potential infringements on annual allowable harvest targets as an approach to estimate threats from the invasive wood wasp, Sirex noctilio Fabricius (Hymenoptera: Siricidae), to the forest products sector of Canada. The approach proposed by these authors uses present-day harvest levels as a reference level to estimate when and 
where the impact of this wasp could become economically damaging.

Detailed studies of the natural history of Pissodes strobi, and of the recovery and defect formation in its coastal host, Sitka spruce was used to develop a computer model, Spruce Weevil Attack (SWAT) (full details of model in Alfaro et al. 1996), capable of comparing losses at the stand level under various weevil and forest management scenarios. Working as a subroutine of the British Columbia Ministry of Forests Tree and Stand Simulator (Mitchell 1975, 1988), the SWAT model, is able to integrate different management options, such as sanitation thinning, and use of genetic resistance to weevil to mitigate the damage, and of forecasting stand productivity at rotation (Figs. 1-3).

\section{Risk assessment in regenerating forests}

The framework proposed by Fuentealba et al. (2013) is used here to illustrate the usefulness of conducting a pest risk assessment before planting. The framework consists of four main steps. The first step is to evaluate the level of hazard or probability of occurrence of insect damage in the young stand. Factors such as geographic location, temperature, precipitation, humidity, seedling vulnerability, and proximity to infested plantations, can all affect the likelihood of insect attack in young stands. For example, low temperatures and humidity can negatively affect feeding and oviposition behaviour of adult white pine weevils, as well as, retard larval development, increasing exposure of weevil larvae to natural enemies (Alfaro et al. 1995). White spruce trees that have a late bud break are less susceptible to spruce bud moth defoliation than those that have an early

Fig. 2. Merchantable volume/ha versus stand age in a Sitka spruce plantation after simulated weevil infestations based on the Spruce Weevil Attack (SWAT) model. Weevil attack began at age six and lasted until age 40 years. Plantation was started at close spacing $(2.74 \mathrm{~m})$, on a site index of $30 \mathrm{~m}$ at breast height age of 50 years.

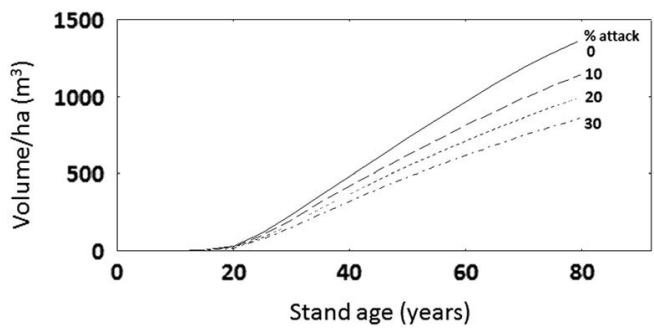

Fig. 1. Results of the Spruce Weevil Attack (SWAT) simulation model showing the dynamics of weevil population, represented by the number of eggs laid on leaders and resulting damage (number of killed leaders) through the life of a Sitka spruce forest from plantation to harvest. In this model, weevil population is regulated by the availability of long leaders (a proxy for food supply), which are more prevalent during the juvenile stage of the stand.

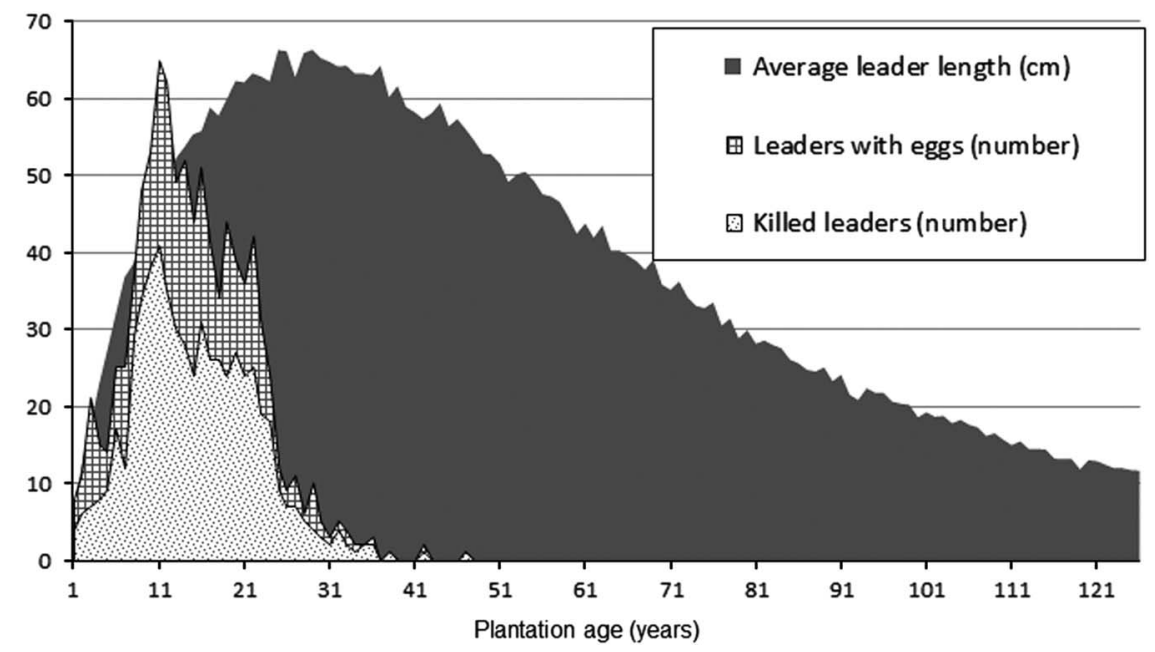


Fig. 3. Merchantable volume/ha versus stand age after simulated weevil infestations using the Spruce Weevil Attack (SWAT) model on Sitka spruce. Plantation was thinned at age 25 to remove $25 \%$ of the basal area, biasing the thinning to give priority to removal of trees with weevil-induced defects, such as major crooks and forks.

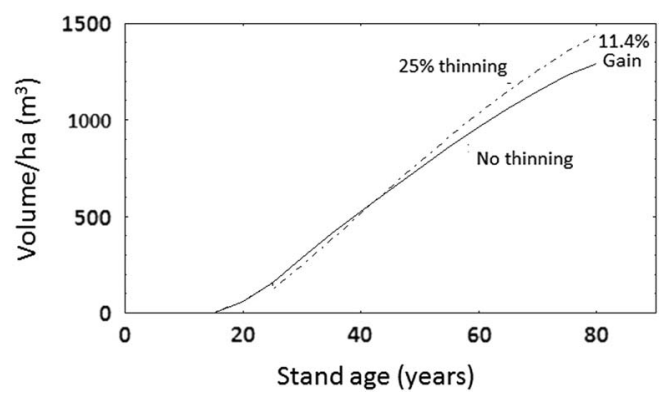

bud break (Quiring 1994). Young lodgepole pine mortality caused by Warren root collar weevil in reforested stands increases when unsalvaged, mature stands killed by mountain pine beetle are nearby (Klingenberg et al. 2010). Climate-based hazard rating systems for specific pest insects can be of great use for reforestation planning, prioritising areas for control treatments, and deciding on the implementation of other pest management tactics, such as where to deploy resistant genotypes (Alfaro et al. 1995).

Second, the level of risk exposure, or economic evaluation of potential impact must be determined, assuming different levels of pest activity (scenario building), to determine the economic threshold or pest level that will cause economic damages of greater value than the cost of the control actions. The impact models described above are useful in this phase of the risk assessment to guide practitioners in determining if the losses caused by the pests are tolerable, or whether control measures are required to avoid plantation failure. Pest control measures will be recommended in those situations where scenario building indicates, for the most likely pest level, that economic losses will significantly surpass the combined economic and ecological cost of control.

The third step consists of determining the vulnerability of the planted stock. The selection of tree species and subspecies to plant is critical to keep pest damage at low levels. The mechanisms of tree defence and genetic resistance to pest species found in the planting stock must be evaluated to determine what tree species or provenances are less prone to be damaged. Unfortunately, this information is missing for most pests of young stands, but when available, this assessment allows choice of planting stock with resistance according to risk level in the selected sites. For example, a successful breeding programme in Sitka spruce resulted in the commercial availability of stock with resistance to white pine weevil in British Columbia (Alfaro et al. 2013). This programme succeeded in identifying sources of heritable and stable resistance against this weevil, allowing the establishment of seed orchards for the commercialisation of resistant seed. The deployment of resistant seedlings is expected to result in a reduction of over $80 \%$ in weevil attack levels (Alfaro et al. 2013). In Québec, the observation of white spruce trees resistant to spruce budworm initiated a programme lead by researchers from Université Laval (Ville de Québec, Québec, Canada) to study the sources of this natural resistance and how to use it to mitigate spruce budworm damage. Preliminary results suggest that two phenolic compounds reduce the pressure of spruce budworm herbivory on specific host tree phenotypes (Delvas et al. 2011).

The final step in risk assessment consists of determining the appropriate management response. The least expensive option for risk mitigation is prevention. Having established the hazard, exposure, and assessed tree species vulnerability to pest damage, it is necessary to prepare a plan for communicating and reducing risk. It is important to clearly communicate the level of risk under different situations to the public and to practitioners. This will effectively facilitate the acceptance and adoption of preventative control measures.

\section{Management of pests of young stands}

Responses to pest situations must be based on the management objectives for the plantation (i.e., values at risk, products expected at rotation), local pest status (e.g., pest is active in the vicinity), tree species vulnerability, and feasibility. Feasibility of pest control varies because options are never $100 \%$ effective, and thus, it is necessary to estimate the level of damage that will occur in spite of the control measures being applied. 
The use of insecticides was often recommended in the past for direct control of pest damage. However, this tactic is now considered environmentally undesirable because of its potential impact on non-target organisms. Furthermore, the development of pest resistance to insecticides has encouraged researchers and practitioners to explore alternative pest control strategies. In the last decades there has been an increase in the use of biological insecticides such as Bacillus thuringiensis kurstaki (Bacillaceae) (Btk) to reduce the damage produced by Lepidoptera, such as spruce budworm (e.g., Fuentealba et al. 2015). Also, there has been an increased interest in classical biological control programmes for controlling pests of young stands, such as the European pine shoot moth in Chile, where the parasitoid Orgillus obscurator Ness (Hymenoptera: Braconidae) was used to control this invasive moth (Alfaro et al. 2010).

The risk assessment framework described previously can be used as a basis for decision-making in an integrated pest management system (IPM). Integrated pest management is an ecological approach to pest control with the objective of using a combination of various tactics to reduce damage rather than to eliminate the pest. An effective IPM system could include the following components: use of planting stock with genetic resistance to the pest insect and tactics that reduce damage based on silviculture, such as shade conservation or increasing plantation density (Alfaro et al. 1995, Lavallée et al. 2001). Integrated pest management aims at reducing the loss of productivity of a site by optimising the selection of the appropriate combination of control methods that lead to a profitable crop. The economic value of the various possible combinations of tactics, provided by the risk assessment, will assist foresters in their selection of the best control method combination.

Intensive research programmes in British Columbia on the natural history, damage, and control of the white pine weevil, permitted the development of an IPM system for this pest (Alfaro et al. 1995), which was formulated to combine silviculture-driven and host resistance-driven tactics. The system relies on accurate risk assessment of plantation sites and requires continuous monitoring of attack levels and the forecasting of plantation productivity under various IPM tactics through the use of a decision support system (Alfaro et al. 1995).

\section{Conclusion}

A number of insect species in a variety of families and orders cause damage to young Canadian forests. Successful management of pests of regenerating forests requires detailed information on the natural history of the damaging organism, including the factors that increase risk, and a careful assessment of the risk mitigation options. Decision support systems, in the form of stand or landscape models capable of incorporating pest management options are required to guide decisions in terms of the expected yields under various pest management scenarios. Risk assessment and IPM system are useful tools to guide practitioners in management of pests of regenerating forests. The fact that 154 of the 179 references cited in this review are by Canadian researchers indicate that Canadians have been active contributors to the research that advanced this field from the early descriptive studies to the development of practical tools to assist industry in managing pests of young forests.

\section{Acknowledgments}

The authors wish to thank to the two anonymous reviewers for their useful suggestions.

\section{References}

Alfaro, R.I. 1982. Fifty year-old Sitka spruce plantations with a history of intense weevil attack. Journal of the Entomological Society of British Columbia, 79: $62-65$.

Alfaro, R.I. 1986. Mortality and top-kill in Douglas-fir following defoliation by the western spruce budworm in British Columbia. Journal of the Entomological Society of British Columbia, 83: 19-26.

Alfaro, R.I. 1989. Stem defects in Sitka spruce induced by Sitka spruce weevil, Pissodes strobi (Peck). In Insects affecting reforestation: biology and damage. Proceedings of a meeting of the IUFRO working group on insects affecting reforestation held under the auspices of the XVIII International Congress of Entomology, 3-9 July 1988, Vancouver, BC. Edited by R.I. Alfaro and S. Glover. Forestry Canada, Victoria, British Columbia, Canada. Pp. 177-185.

Alfaro, R.I. 1991. Damage assessment and integrated pest management of forest defoliators. Forest Ecology and Management, 39: 275-281. 
Alfaro, R.I., Berg, J., and Axelson, J. 2014. Periodicity of western spruce budworm in southern British Columbia, Canada. Forest Ecology and Management, 315: 72-79.

Alfaro, R.I., Borden, J.H., Fraser, R.G., and Yanchuck, A. 1995. The white pine weevil in British Columbia: basis for an integrated pest management system. Forestry Chronicle, 71: 66-73.

Alfaro, R.I., Brown, R., Mitchell, K., Polsson, K., and McDonald, R. 1996. SWAT: a decision support system for spruce weevil management. In Decision support systems for forest pest management. Edited by T.L. Shore and D.A. McLean. Proceedings of a Workshop at the Joint Meeting of the Entomological Society of Canada and British Columbia, 17 October 1995. Forest Resource Development Agreement Report 260. Victoria, British Columbia, Canada. Pp. 31-41.

Alfaro, R.I., Hantula, J., Carroll, A., Battisti, A., Fleming, R., Woods, A., et al. 2010. Forest health in a changing environment. In Forests and society responding to global drivers of change. Edited by G. Mery, P. Katila, G. Galloway, R.I. Alfaro, M. Kanninen, M. Lobovikov, and J. Varjo. International Union of Forest Research Organizations, Vienna, Austria. Pp. 113-134.

Alfaro, R.I., King, J.N., and vanAkker, L. 2013. Delivering Sitka spruce resistance against white pine weevil in British Columbia, Canada. Forestry Chronicle, 89: 235-245.

Alfaro, R.I., van Sickle, G.A., Thomson, A.J., and Wegwitz, E. 1982. Tree mortality and radial growth losses caused by the western spruce budworm in a Douglas-fir stand in British Columbia. Canadian Journal of Forest Research, 12: 780-787.

Amirault, P.A. and Pope, B. 1989. Pest distribution and impact in young lodgepole pine stands in west-central Alberta. Prepared under the Canada-Alberta Forest Resource Development Agreement. Report Project 1410-65. Northern Forestry Centre, Edmonton, Alberta, Canada.

Amman, G.D. and Safranyik, L. 1984. Insects of lodgepole pine: impacts and control. In Proceedings of the symposium on lodgepole pine: the species and its management, 14-16 May 1984, Spokane, WA. Edited by D.H. Baumgartner, D.H. Krebill, J.T. Arnott, and G.F. Weetman. Cooperative Extension, Washington State University, Pullman, Washington, United States of America. Pp. 107-124.

Averill, R.D., Wilson, L.F., and Fowler, R.F. 1982. Impact of the redheaded pine sawfly (Hymenoptera Diprionidae) on young red pine plantations. Great Lakes Entomologist, 15: 65-91.

Balch, R.E. 1952. Studies on the balsam woolly aphid, Adelges piceae (Ratz.) (Homoptera: Phylloxeridae) and its effects on balsam fir, Abies balsamea (L.). Mill. Publication 867. Canadian Department of Agriculture, Ottawa, Ontario, Canada.

Béique, R. 1960. The importance of the European pine shoot moth, Rhyacionia buoliana (Schiff.) in Quebec City and vicinity. The Canadian Entomologist, 92: 858-862.
Benjamin, D.M. 1955. The biology and ecology of the red-headed pine sawfly. Technical Bulletin 1118. United States Department of Agriculture Forest Service, Washington, District of Columbia, United States of America.

Bennet, R.G. 1994. Cone and seed insects of pines, spruces and western larch. In Biology, damage and management of seed orchard pests. Edited by J.J. Turgeon and P. de Groot. Information Report FPM-X-89. Forest Pest Management Institute, Canadian Forest Service, Natural Resources Canada, Sault Ste. Marie, Ontario, Canada. Pp. 1-13.

Billany, D.J., Carter, C.I., Winter, T.G., and Fielding, N.J. 1983. The effects of climate and parasites on Gilpinia hercyniae (Hartig) (Hym: Diprionidae) in Britain. Entomologist's Monthly Magazine, 119: 117-120.

Blackman, M.W. 1941. Bark beetles of the genus Hylastes Erichson in North America. United States Department of Agriculture Miscellaneous Publication, 417: 1-27.

Blais, J.R. 1965. Spruce budworm outbreaks in the past three centuries in the Laurentide Park, Quebec. Forest Science, 11: 130-138.

Boucher, D., Lavallée, R., and Mauffette, Y. 2001. Biological performance of the white pine weevil in relation to the anatomy of the resin canal system of four different host species. Canadian Journal of Forest Research, 31: 2035-2041.

British Columbia Ministry of Forests and Range. 2009. Larch cone adelgid (Adelges lariciatus). Cone and Seed Insect Pest Leaflet 9, British Columbia Ministry of Forests and Range, Victoria, British Columbia, Canada. Available from http://www.fgcouncil.bc.ca/ PM-Factsheet09-Adelges-lariciatus.pdf [accessed 26 March 2015].

Burleigh, J.S., Alfaro, R.I., and Borden, J.H. 2002. Historical and spatial characteristics of spruce budworm Choristoneura fumiferana (Clem.) (Lepidoptera: Tortricidae) in northeastern British Columbia. Forest Ecology and Management, 168: 301-309.

Canadian Council of Forest Ministers. 2013. Forest insect national tables for areas of moderate to severe defoliation. Canadian Council of Forest Ministers. Available from http://nfdp.ccfm.org/data/compendium/ html/comp_41e.html [accessed 22 May 2013].

Carroll, A.L., Lawlor, M.F., and Quiring, D.T. 1993. Influence of feeding by Zeiraphera canadensis, the spruce bud moth, on stem-wood growth of young white spruce. Forest Ecology and Management, 58: 41-49.

Cerezke, H.F. 1970. A method for estimating abundance of the weevil, Hylobius warreni Wood, and its damage in lodgepole pine stands. Forestry Chronicle, 46: 392-396.

Cerezke, H.F. 1972. Observations on the distribution of the spruce bud midge (Rhabdophaga swainei Felt) in black and white spruce crowns and its effect on height growth. Canadian Journal of Forest Research, 2: 69-72. 
Cerezke, H.F. 1994. Warren rootcollar weevil, Hylobius warren Wood (Coleoptera: Curculionidae), in Canada: ecology, behavior, damage relationships, and management. The Canadian Entomologist, 126: 1383-1442.

Cerezke, H.F. and Brandt, J.P. 1993. Forest insect and disease conditions in Alberta, Saskatchewan, Manitoba and the Northwest Territories in 1992. Information Report NOR-X-332. Forestry Canada, Northwest Region, Northern Forestry Centre, Edmonton, Alberta, Canada.

Cerezke, H.F., Dhir, N.K., and Barnhardt, L.K. 2011. Surveys of damage agents affecting young tree genetics research plantations and seed orchards in Alberta and a summary of control treatments (revised). Alberta Sustainable Resource Development Forest Management Branch, Edmonton, Alberta, Canada.

Cerezke, H.F. and Pendrel, B.A. 1995. Root collar weevils, Hylobius and Steremnius spp. In Forest insect pests in Canada. Edited by J.A. Armstrong and W.G.H. Ives. Natural Resources Canada, Canadian Forest Service, Ottawa, Ontario, Canada. Pp. 253-263.

Cerezke, H.F. and Volney, W.J.A. 1995. Forest insect pests in the Northwest region. In Forest insect pests in Canada. Edited by J.A. Armstrong and W.G.H. Ives. Natural Resources Canada, Canadian Forest Service, Ottawa, Ontario, Canada. Pp. 59-72. Cerezke, H.F., Volney., W.J.A., Mallett, K.I., and Emond, F.J. 1989. Assessment of forest insect, disease and stand conditions in Cypress Hills Provincial Park, Saskatchewan. Department of Agriculture, Ministry of State for Forestry and Mines, Canadian Forestry Service, Northwest Region, Edmonton, Alberta, Canada.

Ciesla, W.M. 2011. Forest entomology: a global perspective. Wiley-Blackwell, Chichester, United Kingdom.

Clark, J. 1952. The spruce bud midge, Rhabdophaga swainei Felt (Cecidomyiidae: Diptera). The Canadian Entomologist, 84: 87-89.

Cloutier, C., Mailhot, P., and Brodeur, J. 2006. La cécidomyie du sapin de noël a-t-elle trop d'ennemis naturels? Le Naturaliste Canadien, 130: 32-36.

Condrashoff, S.F. 1968. Biology of Steremnius carinatus (Coleoptera: Curculionidae), a reforestation pest in coastal British Columbia. The Canadian Entomologist, 100: 386-394.

Coppel, H.C. and Leius, K. 1955. History of the larch sawfly, with notes on origin and biology. The Canadian Entomologist, 87: 103-111.

Coulson, R.N. and Witter, J.A. 1984. Forest entomology: ecology and management. John Wiley and Sons, New York, New York, United States of America.

Cozens, R.D. 1985. Insect and disease risk factors in established interior spruce plantations. MF Thesis. University of British Columbia, Vancouver, British Columbia, Canada. Available from https://circle. ubc.ca/handle/2429/24426 [accessed 9 June 2015].
Cumming, M.E.P. 1959. The biology of Adelges cooleyi (Gill.) (Homoptera: Phylloxeridae). The Canadian Entomologist, 91: 601-617.

Cumming, M.E.P. 1962. A monomorphic cycle of Adelges cooleyi (Gill.) (Homoptera: Phylloxeridae) living only in spruce. The Canadian Entomologist, 94: 1190-1195.

Cumming, M.E.P. 1968. The life history and morphology of Adelges lariciatus (Homoptera: Phylloxeridae). The Canadian Entomologist, 100: 113-126.

Cunningham, J.C. 1984. Neodiprion abietis (Harris), balsam fir sawfly (Hymenoptera: Diprionidae). In Biological control programmes against insects and weeds in Canada 1969-1980. Edited by J.S. Kellerher and M.A. Hulme. Commonwealth Agricultural Bureaux, Farnham, Slough, United Kingdom. Pp. 321-322.

Cunningham, J.C. and de Groot, P. 1984. Neodiprion lecontei (Fitch), redheaded pine sawfly (Hymenoptera: Diprionidae). In Biological control programmes against insects and weeds in Canada 1969-1980. Edited by J.S. Kellerher and M.A. Hulme. Commonwealth Agricultural Bureaux, Farnham, Slough, United Kingdom. Pp. 323-329.

Dawson, A.F. 1971. Balsam twig aphid in British Columbia. Pest Leaflet 36. Environment Canada, Canadian Forestry Service, Pacific Forest Research Centre, Victoria, British Columbia, Canada.

DeBoo, R.F., Sippell, W.L., and Wong, H.R. 1971. The eastern pine-shoot borer, Eucosma gloriola (Lepidoptera: Tortricidae), in North America. The Canadian Entomologist, 103: 1473-1486.

de Groot, P. 1995. Yellowheaded spruce sawfly, Pikonema alaskensis. In Forest insect pests in Canada. Edited by J.A. Armstrong and W.G.H. Ives. Natural Resources Canada, Canadian Forest Service, Ottawa, Ontario, Canada. Pp. 241-244.

de Groot, P., Hopkin, A.A., and Sajan, R.J. 2003. Forest management guidelines for major insects and diseases of spruce, pine and aspen in eastern Canada. Natural Resources Canada, Canadian Forest Service, Great Lakes Forestry Centre, Sault Ste, Marie, Ontario, Canada.

Delvas, N., Bauce, É., Labbé, C., Ollevier, T., and Belanger, R. 2011. Phenolic compounds that confer resistance to spruce budworm. Entomologia Experimentalis et Applicata, 141: 35-44.

Dreger-Jauffret, F. and Shorthouse, J.D. 1992. Diversity of gall-inducing insects and their galls. In Biology of insect-inducing galls. Edited by J.D. Shorthouse and O. Rohfritsch. Oxford University Press, New York, New York, United States of America. Pp. 8-33.

Drooz, A.T. 1985. Insects of eastern forests. Miscellaneous publication 1426. United States Department of Agriculture, Forest Service, Washington, District of Columbia, United States of America. 
Drouin, J.A. and Kusch, D.S. 1981. Chemical control trials on the northern pitch twig moth in Alberta. Tree Planters' Notes, 32: 18-20.

Drouin, J.A., Sullivan, C.R., and Smith, S.G. 1963. Occurrence of Pissodes terminalis Hopp. (Coleoptera: Curculionidae) in Canada: life history, behaviour, and cytogenetic identification. The Canadian Entomologist, 95: 70-76.

Eckhardt, L.G., Goyer, M.A., Klepzig, K.D., and Jones, J.P. 2004. Interactions of Hylastes species (Coleoptera: Scolytidae) with Leptographium species associated with loblolly pine decline. Journal of Economic Entomology, 97: 468-474.

Eckhardt, L.G., Weber, A.M., Menard, R.D., Jones, J.P., and Hess, N.J. 2007. Insect-fungal complex associated with loblolly pine decline in central Alabama. Forest Science, 53: 84-92.

Emond, F.J. and Still, G.G. 1974. Forest insect and disease conditions in Manitoba provincial parks, 1973. Information Report NOR-X-91. Forestry Canada, Northern Forest Research Centre, Edmonton, Alberta, Canada.

Environment and Sustainable Resource Development Alberta. 2008. Annual report: forest health in Alberta 2007 [online]. Available from http://esrd. alberta.ca/lands-forests/forest-health/forest-health-andadaptation-annual-reports.aspx [accessed 26 March 2015].

Environment and Sustainable Resource Development Alberta. 2010. Annual report: forest health in Alberta 2009 [online]. Available from http://esrd. alberta.ca/lands-forests/forest-health/forest-health-andadaptation-annual-reports.aspx [accessed 26 March 2015].

Environment and Sustainable Resource Development Alberta. 2013. Annual report: forest health in Alberta 2012 [online]. Available from http://esrd. alberta.ca/lands-forests/forest-health/forest-health-andadaptation-annual-reports.aspx [accessed 26 March 2015].

Erickson, R.D. and Hughes, M.T. 1982. Black vine weevil damage Victoria. FIDS Pest Report, Environment Canada, Canadian Forestry Service, Pacific Forest Research Centre, Victoria, British Columbia, Canada.

Evans, H.J., Lawrence, H.D., Ingram, W.A., and Czerwinski, E.J. 2002. Forest health conditions in the southcentral region of Ontario. Information report, Canadian Forest Service, Natural Resources Canada, Sault Saint Marie, Ontario, Canada. Available from http://www.glfc.forestry.ca/VLF/ foresthealth/sc_regional_report_2002.pdf [accessed 9 June 2015].

Finnegan, R.J. 1959. The pales weevil, Hylobius pales (Hbst.), in southern Ontario. The Canadian Entomologist, 91: 664-670.

Finnegan, R.J. 1962. The pine root-collar weevil, Hylobius radicis Buch., in southern Ontario. The Canadian Entomologist, 94: 11-17.

Friend, R.B. and Wilford, B.H. 1933. The spruce gall aphid as a forest pest. Journal of Forestry, 31: 816-825.
Fuentealba, A., Alfaro, R.I., and Bauce, É. 2013. Theoretical framework for assessment of risks posed to Canadian forests by invasive insect species. Forest Ecology and Management, 302: 97-106.

Fuentealba, A., Bauce, É., and Dupont, A. 2015. Bacillus thuringiensis efficacy in reducing spruce budworm damage as affected by host tree species. Journal of Pest Science, In press, doi: 10.1007/ s10340-014-0629-8.

Furniss, M.M. and Carolin, V. 1977. Western forest insects. United States Department of Agriculture Miscellaneous Publication, 1339: 1-654.

Gagné, R.J. 1978. A systematic analysis of the pine pitch midges, Cecidomyia spp. (Diptera: Cecidomyiidae). Miscellaneous Publication 1339. United States Department of Agriculture Forest Service, Washington, District of Columbia, United States of America.

Grant, J. 1966. The hosts and distribution of the root weevils Hylobius pinicola (Couper) and $H$. warreni Wood in British Columbia. Journal of the Entomological Society of British Columbia, 63: 3-4.

Greenbank, D.O. 1970. Climate and the ecology of the balsam woolly aphid. The Canadian Entomologist, 102: $546-578$.

Griffiths, K.J., Cunningham, J.C., and Otvos, I.S. 1984. Neodiprion sertifer (Fitch), European pine sawfly (Hymenoptera: Diprionidae). In Biological control programmes against insects and weeds in Canada 1969-1980. Edited by J.S. Kellerher and M.A. Hulme. Commonwealth Agricultural Bureaux, Farnham, Slough, United Kingdom. Pp. 331-340.

Gross, H.L. 1985. Impact of pests on the white pine resources of Ontario. Proceedings of the Entomological Society of Ontario, 116: 33-37.

Hall, J.P., Bowers, W.W., and Hirvonen, H.E. 1998. Forest insect and disease conditions in Canada 1995. FIDS Report, Natural Resources Canada, Canadian Forest Service, Headquarters, Science Branch, Ottawa, Ontario, Canada.

Harris, J.W.E. and Bowers, W.W. 1995. Wolly adelgids. In Forest insect pests in Canada. Edited by J.A. Armstrong and W.G.H. Ives. Natural Resources Canada, Canadian Forest Service, Ottawa, Ontario, Canada. Pp. 289-292.

Heeley, T., Alfaro, R.I., Humble, L., and Strong, W.L. 2003. Distribution and life cycle of Rhyacionia buoliana (Lepidoptera: Tortricidae) in the interior of British Columbia. Journal of the Entomological Society of British Columbia, 100: 19-25.

Heppner, D. and Turner, J. 2006. Spruce weevil and western spruce budworm forest health stand establishment decision aids. British Columbia Journal of Ecosystems and Management, 7: 45-49.

Howse, G.M. 1995. Forest insect pests in the Ontario region. In Forest insect pests in Canada. Edited by J.A. Armstrong and W.G.H. Ives. Natural Resources Canada, Canadian Forest Service, Ottawa, Ontario, Canada. Pp. 41-57. 
Howse, G.M. and Meating, J.H. 1995. Jack pine budworm situation in Ontario 1981-1994. In Jack pine budworm biology and management. Proceedings of the jack pine bud worm symposium, 24-26 January 1995. Winnipeg, Manitoba. Edited by W.J.A. Volney, V.G. Nealis, C.M. House, A.R. Westwood, D.R. McCuilough, and B.L. Laishley. Information Report NOR-X-342. Natural Resources Canada. Canadian Forest ServiceNorthern, Edmonton, Alberta, Canada.

Hudak, J. and Raske, A.G. 1995. Forest pests in the Newfoundland and Labrador region. In Forest insect pests in Canada. Edited by J.A. Armstrong and W.G.H. Ives. Natural Resources Canada, Canadian Forest Service, Ottawa, Ontario, Canada. Pp. 1-9.

Humble, L.M., Shepherd, R.F., and Maher, T.F. 1989. Biology, outbreak characteristics and damage caused by the black army cutworm (Lepidoptera: Noctuidae). In Proceedings of a meeting of the IUFRO working group on insects affecting reforestation (S2.07-03) held under the auspices of the XVIII International Congress of Entomology, 3-9 July 1988, Vancouver, BC, Canada. Edited by R.I. Alfaro and S.G. Glover. Insects affecting reforestation: biology and damage. Forestry Canada, Pacific Centre, Victoria, British Columbia, Canada. Pp. 82-88.

Humble, L.M. and West, R.J. 1995. Cecidomyiidae gall midges. In Forest insect pests in Canada. Edited by J.A. Armstrong and W.G.H. Ives. Natural Resources Canada, Canadian Forest Service, Ottawa, Ontario, Canada. Pp. 265-269.

Hunter, M.D. 2001. Out of sight, out of mind: the impacts of root-feeding insects in natural and managed systems. Agricultural and Forest Entomology, 3: 3-9.

Hunter, M.D. 2008. Root herbivory in forest ecosystems. In Root feeders: an ecosystem perspective. Edited by S.N. Johnson and P.J. Murray. CABI, Wallingford, United Kingdom. Pp. 68-95.

Ingram, W., Curry, D., Francis, M., and Rowlinson, D. 1997. Forest health conditions in the south central region of Ontario in 1996. Information Report. Canadian Forest Service, Natural Resources Canada, Sault Saint Marie, Ontario, Canada.

Ives, W.G.H. and Rentz, C.L. 1993. Factors affecting the survival of immature lodgepole pine in the foothills of west-central Alberta. Information Report NOR-X-330. Forestry Canada, Northern Forestry Centre, Edmonton, Alberta, Canada.

Ives, W.G.H. and Wong, H.R. 1988. Tree and shrub insects of the Prairie Provinces. Information Report NOR-X-292. Canadian Forest Service, Northern Forestry Centre, Edmonton, Alberta, Canada.

Jacobi, W.R. 1992. Potential insect vectors of the black stain root disease pathogen on southern Vancouver Island. Journal of the Entomological Society of British Columbia, 89: 54-56.

Jacobi, W.R., Zeglen, S., and Beale, J.D. 2008. Black stain root disease progression in coastal Douglas-fir in British Columbia. Canadian Journal of Plant Pathology, 30: 339-344.
Johns, R.C. and Quiring, D.T. 2010. Spatial heterogeneity within an evergreen conifer promotes foliage-age dietary mixing by a specialist herbivore. Animal Behaviour, 80: 659-666.

Katovich, S.A., McCullough, D.G., and Haack, R.A. 1995. Yellowheaded spruce sawfly - its ecology and management. General Technical Report NC-179. United States Department of Agriculture Forest Service, North Central Forest Experiment Station, Saint Paul, Minnesota, United States of America.

Kelton, L.A. 1975. The lygus bugs (genus Lygus Hahn) of North America (Heteroptera: Miridae). Memoirs of the Entomological Society of Canada, 95: 1-101.

Klingenberg, M.D., Lindgren, B.S., Gillingham, M.P., and Aukema, B.H. 2010. Management response to one insect pest may increase vulnerability to another. Journal of Applied Ecology, 47: 566-574.

Knight, F.B. and Heikkenen, H.J. 1980. Principles of forest entomology, 5th edition, McGraw-Hill Book Company, New York, New York, United States of America.

Kondo, E.S. and Moody, B.H. 1987. Forest insect and disease conditions in Canada 1986. Forest Insect and Disease Survey Report, Canadian Forestry Service, Headquarters, Ottawa, Ontario, Canada.

Kovacs, E. and McLean, J.A. 1990. Emergence patterns of terminal weevils (Coleoptera: Curculionidae) and their parasitoids from lodgepole pine in the interior of British Columbia, Canada. Journal of the Entomological Society of British Columba, 87: 75-79.

Lachance, D. 1995. Forest insect pests in the Quebec region. In Forest insect pests in Canada. Edited by J.A. Armstrong and W.G.H. Ives. Natural Resources Canada, Canadian Forest Service, Ottawa, Ontario, Canada. Pp. 27-39.

Lachance, D., Thibault, J., and Monnier, C. 1991. Insectes et maladies des forêts dans la region de Québec de 1936 à 1988. Forestry Canada Quebec Region Information Report LAU-X-97. Forestry Canada, Sainte-Foy, Québec, Canada.

Langor, D.W., Drouin, J.A., and Wong, H.R. 1992. The lodgepole terminal weevil in the Prairie Provinces. Forest management note 55. Forestry Canada, Northwest Region, Northern Forestry Centre, Edmonton, Alberta, Canada.

Langor, D.W. and Williams, D.J.M. 1998. Life cycle and mortality of Pissodes terminalis (Coleoptera: Curculionidae) in lodgepole pine. The Canadian Entomologist, 130: 387-397.

Lavallée, R., Daoust, G., Mauffette, Y., Audet, G., and Coulombe, C. 2001. Feeding, oviposition and emergence of the white pine weevil (Pissodes strobi (Peck)) under a pioneer broad-leaved forest canopy 2001. Forestry Chronicle, 77: 885-892.

Lejeune, R.R. 1947. Status of the larch sawfly, Pristiphora erichsonii HTG., in the prairie provinces. The Canadian Entomologist, 79: 130-134.

Lejeune, R.R. 1962. A new reforestation problem by a weevil Steremnius carinatus Boh. Canada Department of Forestry, Forest Entomology and Pathology Branch, Bi-monthly Progress Report, 18: 3. 
Machial, L.A., Lindgren, S., and Aukema, B.H. 2012. The role of vision in the host orientation behaviour of Hylobius warreni. Agricultural and Forest Entomology, 14: 286-294.

Maclauchlan, L.E. and Borden, J.H. 1996. Spatial dynamics and impacts of Pissodes terminalis (Coleoptera: Curculionidae) in regenerating stands of lodgepole pine. Forest Ecology and Management, 82: 103-113.

MacLean, D.A. 1980. Vulnerability of fir-spruce stands during uncontrolled spruce budworm outbreaks: a review and discussion. Forestry Chronicle, 56: 213-221.

Magasi, L. 1983. Forest pest conditions in the Maritimes 1982. Information Report M-X-141. Maritimes Forest Research Centre, Fredricton, New Brunswick, Canada. Available from https://afc-fr. cfsnet.nfis.org/fias/pdfs/afc/atlantic_information_MX141.pdf [accessed 6 June 2015].

Magasi, L. 1989. Forest pest conditions in the Maritimes 1988. Region Information Report M-X-174. Environment Canada, Canadian Forestry Service, Maritimes Region, Fredericton, New Brunswick, Canada.

Magasi, L. 1995. Forest insect pests in the Maritimes Region. In Forest insect pests in Canada. Edited by J.A. Armstrong and W.G.H. Ives. Natural Resources Canada, Canadian Forest Service, Ottawa, Ontario, Canada. Pp. 11-25.

Maher, T.F. and Shepherd, R.F. 1992. Mortality and height growth losses of coniferous seedlings damaged by the black army cutworm. Canadian Journal of Forest Research, 22: 1364-1370.

Martin, J.L. 1960. Life history of the pine tip moth, Rhyacionia adana Heinrich, in Ontario (Lepidoptera: Olethreutidae). The Canadian Entomologist, 92: 724-728.

Martin, J.L. 1964. The insect ecology of red pine plantations in central Ontario. II. Life history and control of Curculionidae. The Canadian Entomologist, 96: 1408-1417.

Martineau, R. 1984. Insects harmful to forest trees. Canadian Forestry Service, Forestry Technical Report 32. Multiscience Publications Ltd, Ottawa, Ontario, Canada.

McCulloch, L., Aukema, B., White, K., and Klingenberg, M. 2009. Warren root collar weevil stand establishment decision aid. BC Journal of Ecosystems and Management, 10: 105-107.

McLeod, J.M. and Tostowaryk, W. 1971. Outbreaks of pitch nodule makers (Petrova spp.) in Quebec jack pine forests. Information Report Q-X-24. Forestry Canada, Laurentian Forest Research Centre, Ville de Québec, Québec, Canada.

Ministère des Ressources naturelles. 2000. Insectes et maladies des arbres. Portrait statistique-Bilan annuel 1999. Gouvernement du Québec, Ville de Québec, Québec, Canada.

Ministère des Ressources naturelles et de la Faune. 2012. Insectes, maladies et feux dans les forêts québécoises. Bilan 2011. Ministère des Ressources naturelles et de la Faune, Gouvernement du Québec, Ville de Québec, Québec, Canada.
Mitchell, K.J. 1975. Dynamics and simulated yield of Douglas-fir. Forest Science Monograph, 17: 1-39.

Mitchell, K.J. 1988. SYLVER: modelling the impact of silviculture on yield, lumber value, and economic return. Forestry Chronicle, 64: 127-131.

Moody, B.H. 1992. Forest insect and disease conditions in Canada, 1989. Forest Insect and Disease Survey, Canadian Forestry Service, Petawawa National Forestry Institute, Chalk River, Ontario, Canada.

Moreau, G. 2006. Past and present outbreaks of the balsam fir sawfly: an analytical review. Forest Ecology and Management, 221: 215-219.

Mutuura, A. and Freeman, T.N. 1966. The North American species of the genus Zeiraphera, Treitschke (Olethreutidae). Journal of Research on the Lepidotera, 5: 153-176.

Natural Resources Canada. 2014. Canada's forest industry by the numbers [online]. Available from http://www.nrcan.gc.ca/forests/industry/13311 [accessed 18 December 2014].

Nealis, V.G. 1998. Population dynamics of the white pine weevil, Pissodes strobe, infesting jack pine, Pinus banksiana, in Ontario, Canada. Ecological Entomology, 23: 305-313.

Nealis, V.G. 2015. Comparative ecology of coniferfeeding spruce budworms (Lepidoptera: Tortricidae). The Canadian Entomologist, In this issue (published online ahead of print 29 May 2015). doi: http://dx.doi.org/10.4039/tce.2015.15.

New Brunswick Department of Natural Resources Forest Pest Management Section. 2013. Summary of forest pest conditions in New Brunswick in 2012 and outlook for 2013. Government of New Brunswick, Fredericton, New Brunswick, Canada.

Penny, G. 2007. Forest health conditions in Nova Scotia 2007 annual report [online]. Report FOR 2009-3. Nova Scotia Department of Natural Resources, Shubenacadie, Nova Scotia, Canada. Available from http://novascotia. $\mathrm{ca} /$ natr/forestprotection/foresthealth/pdf/up-to-2007Annual-Report.pdf [accessed 19 May 2015].

Petty, J., Gautreau, E.J., and Tidsbury, R.C. 1974. Forest insect and disease conditions in Saskatchewan provincial parks, regional parks and Trans-Canada highway campgrounds, 1973. Information Report NOR-X-95. Forestry Canada, Northern Forest Research Centre, Edmonton, Alberta, Canada.

Piene, H. 1980. Effects of insect defoliation on growth and foliar nutrients of young balsam fir. Forest Science, 26: 665-673.

Piene, H. 1991. The sensitivity of young white spruce to spruce budworm defoliation. Northern Journal of Applied Forestry, 8: 168-171.

Piene, H., Ostaff, D., and Eveleigh, E. 2001. Growth loss and recovery following defoliation by the balsam fir sawfly in young, spaced balsam fir stands. The Canadian Entomologist, 133: 675-686.

Pointing, P.J. 1961. The biology and behaviour of the European pine shoot moth, Rhyacionia buoliana (Schiff.), in southern Ontario. I. Adult. The Canadian Entomologist, 93: 1098-1112. 
Prentice, R.M. 1955. Pine root-collar weevil in Manitoba. Canadian Department of Agriculture, Forest Biology Division, Bi-Monthly Program Report, 11: 1-2.

Price, P.W., Fernandes, W., and Waring, G.L. 1987. Adaptive nature of insect galls. Environmental Entomology, 16: 15-24.

Quiring, D.T. 1992. Rapid change in suitability of white spruce for a specialist herbivore, Zeiraphera canadensis, as a function of leaf age. Canadian Journal of Zoology, 70: 2132-2138.

Quiring, D.T. 1993. Influence of intra-tree variation in time of budburst of white spruce on herbivory and the behaviour and survivorship of Zeiraphera canadensis. Ecological Entomology, 18: 353-364.

Quiring, D.T. 1994. Influence of inter-tree variation in time of budburst of white spruce on herbivory and the behaviour and survivorship of Zeiraphera canadensis. Ecological Entomology, 19: 17-25.

Raske, A.G., Sutton, W.J., Banfield, E.C., Stone, D.M., O'Brien, D.S., Pardy, K.E., et al. 1992. Forest insect and disease conditions in Newfoundland and Labrador in 1991. Information report N-X-288. Forestry Canada, Newfoundland and Labrador Region, St. John's, Newfoundland and Labrador, Canada.

Retnakaran, A. and Harris, J.W.E. 1995. Terminal weevils. In Forest insect pests in Canada. Edited by J.A. Armstrong and W.G.H. Ives. Natural Resources Canada, Canadian Forest Service, Ottawa, Ontario, Canada. Pp. 233-240.

Rose, A.H. and Lindquist, O.H. 1994. Insects of eastern spruces, fir and hemlock. Natural Resources Canada, Canadian Forest Service, Headquarters, Science and Sustainable Development Directorate, Ottawa, Ontario, Canada.

Ross, D.A. and Ilnytzky, S. 1977. The black army cutworm Actebia fennica (Tauscher) in British Columbia. Information Report BC-X-154. Canadian Forest Service, Pacific Forest Research Centre, Victoria, British Columbia, Canada.

Scarr, T.A., Ryall, K.L., and Hodge, P. 2012. Forest health conditions in Ontario 2011. Ontario Government, Ministry of Natural Resources, Sault Saint Marie, Ontario, Canada.

Scarr, T.A., Smith, S.M., Turgeon, J.J., and Howse, G.M. 2001. Insect pest management. In Regenerating the Canadian forest: principles and practice for Ontario. Edited by R.G. Wagner and S.J. Colombo. Fitzhenry \& Whiteside Limited, Markham, Ontario, Canada.

Schroff, A., Lindgren, B.S., and Gillingham, M.P. 2006. Random acts of weevil: a spatial analysis of Hylobius warreni attack on Pinus contorta var. latifolia in the sub-boreal spruce zone of Northern British Columbia. Forest Ecology and Management, 227: 42-49.

Shrimpton, G. 1985. Four insect pests of conifer nurseries in British Columbia. Western Forest Nursery Council - Intermountain Nurseryman's Association. United States Department of Agriculture Forest Service General Technical Report Intermountain Research Station, 185: 119-121.
Silver, G.T. 1968. Studies on the Sitka spruce weevil, Pissodes sitchensis, in British Columbia. The Canadian Entomologist, 100: 93-110.

Simard, S.W. and Hannam, K.D. 2000. Effects of thinning overstory paper birch on survival and growth of interior spruce in British Columbia: implications for reforestation policy and biodiversity. Forest Ecology and Management, 129: 237-251.

Smerlis, E. 1961. Pathological conditions of immature balsam fir stands of hylocomium-oxalis type in the Laurentide Park, Quebec. Forestry Chronicle, 37: 109-115.

South, D.B. 1991. Lygus bugs: a worldwide problem in conifer nurseries. In Proceedings, 1st IUFRO workshop on diseases and insects in forest nurseries. Edited by J.R. Sutherland and S.G. Glover. Information Report BC-X-331. Forestry Canada, Victoria, British Columbia, Canada. Pp. 215-222.

Speight, M.R. and Wainhouse, D. 1989. Ecology and management of forest insects. Oxford University Press, Oxford, United Kingdom.

Stoszek, K.J. 1973. Damage to ponderosa pine plantations by the western pine-shoot borer. Journal of Forestry, 71: 701-705.

Sutherland, J.R., Shrimpton, G.M., and Sturrock, R.N. 1989. Diseases and insects in British Columbia forest seedling nurseries. FRDA Report 065. Forestry Canada/BC Ministry of Forest, Pacific Forestry Centre, Victoria, British Columbia, Canada.

Syme, P.D. 1984. Rhyacionia buoliana (Schiff.), European pine shoot moth (Lepidoptera: Tortricidae). In Biological control programmes against insects and weeds in Canada 1969-1980. Edited by J.S. Kellerher and M.A. Hulme. Commonwealth Agricultural Bureaux, Wallingford, United Kingdom. Pp. 387-396.

Syme, P.D., Grant, G.G., and Gray, T.G. 1995. European pine shoot moth, Rhyacionia buoliana, and other olethreutid. In Forest insect pests in Canada. Edited by J.A. Armstrong and W.G.H. Ives. Natural Resources Canada, Canadian Forest Service, Ottawa, Ontario, Canada. Pp. 271-277.

Thier, R.W. and Marsden, M.A. 1990. Vertical growth response of ponderosa pine infested by western pine shoot borer, Eucosma sonomana Kearfott (Lepidoptera: Olethreutidae). The Canadian Entomologist, 122: 343-347.

Turgeon, J.J. 1985. Life cycle and behaviour of the spruce bud moth, Zeiraphera canadensis (Lepidoptera: Olethrcutidae), in New Brunswick. The Canadian Entomologist, 117: 1239-1247.

Turgeon, J.J. 1986. The phenological relationship between the larval development of the spruce bud moth, Zeiraphera canadensis (Lepidoptera: Olethrcutidae), and white spruce in northern New Brunswick. The Canadian Entomologist, 118: 345-350.

Turgeon, J.J., Kettela, E.G., and Jobin, L. 1995. Spruce bud moth, Zeiraphera canadensis. In Forest insect pests in Canada. Edited by J.A. Armstrong and W.G.H. Ives. Natural Resources Canada, Canadian Forest Service, Ottawa, Ontario, Canada. Pp. 183-192. 
Turnock, W.J. 1953. Some aspects of the life history and ecology of the pitch nodule maker, Petrova albicapitana (Busck) (Lepidoptera: Olethreutidae). The Canadian Entomologist, 85: 233-243.

Turnock, W.J. 1960. Ecological life-history of the larch sawfly, Pristiphora ericsonii (Htg.) (Hymenoptera: Tenthredinidae), in Manitoba and Saskatchewan. The Canadian Entomologist, 92: 500-516.

van Sickle, G.A. 1995. Forest insect pests in the Pacific and Yukon region. In Forest insect pests in Canada. Edited by J.A. Armstrong and W.G.H. Ives. Natural Resources Canada, Canadian Forest Service, Ottawa, Ontario, Canada. Pp. 73-89.

Volney, W.J.A. 1988. Analysis of historic jack pine budworm outbreaks in the prairie provinces of Canada. Canadian Journal of Forest Research, 18: 1152-1158.

Volney, W.J.A., Alfaro, R.I., Bothwell, P., Hogg, E.H., Hopkin, A., Laflamme, G., et al. 2005. A framework for poplar plantation risk assessments. Unasylva, 221: 20-25.

Wallace, D.R. and Cunningham, J.C. 1995. Diprionid sawflies. In Forest insect pests in Canada. Edited by J.A. Armstrong and W.G.H. Ives. Natural Resources Canada, Canadian Forest Service, Ottawa, Ontario, Canada. Pp. 193-232.

Wallace, D.R. and Sullivan, C.R. 1985. The white pine weevil, Pissodes strobi (Coleoptera: Curculionidae): a review emphasizing behaviour and development in relation to physical factors. Proceedings of the Entomological Society of Ontario, 166: 39-62.

Warren, G.L. 1956. The effect of some site factors on the abundance of Hypomolyx piceus (Coleoptera: Curculionidae). Ecology, 37: 132-139.

Warren, G.L. 1960. External anatomy of the adult of Hylobius warreni Wood (Coleoptera: Curculionidae) and comparison with $H$. pinicola (Couper). The Canadian Entomologist, 92: 321-341.

Welty, C. and Houseweart, M.W. 1985. Site influences on Hylobius congener (Coleoptera: Curculionidae), a seedling debarking weevil of conifer plantations in Maine. Environmental Entomology, 14: 826-833.

West, R.J. 1989. The biology, damage and within-tree distribution of the spruce bud midge, Rhabdophaga swainei Felt (Diptera: Cecidomyiidae), on black spruce in Newfoundland. In Insects affecting reforestation: biology and damage. Edited by R.I. Alfaro and Glover S. Proceedings of a meeting of the IUFRO working group on insects affecting reforestation held under the auspices of the XVIII International Congress of Entomology, 3-9 July 1988, Vancouver, BC. Forestry Canada, Victoria, British Columbia, Canada. Pp. 213-223.
West, R.J. and Shorthouse, J.D. 1982. Morphology of the balsam fir needle gall induced by the midge Paradiplosis tumifex (Diptera: Cecidomyiidae). Canadian Journal of Botany, 60: 131-140.

Westfall, J. and Ebata, T. 2011. 2010 Summary of forest health conditions in British Columbia [online]. Pest Management Report 15. British Columbia Ministry of Forests, Mines and Lands, Victoria, British Columbia, Canada. Available from http://www.for. gov.bc.ca/ftp/HFP/external/!publish/Aerial_Overview/ 2010/FH\%20Conditions\%202010.pdf [accessed 6 June 2015].

Whitney, R.D. 1961. Root wounds and associated root rots of white spruce. Forestry Chronicle, 37: 401-411.

Wilson, L.F. and Millers, I. 1983. Pine root collar weevil: its ecology and management. United States Department of Agricuture, Forest Service Technical Bulletin, 1675: 1-34. Available from http://na.fs.fed. us/pubs/misc/prc_weevil/prc_weevil.pdf [accessed 19 May 2015].

Wong, H.R., Drouin, J.A., and Rentz, C.L. 1985. Petrova albicapitana (Busck) and P. metallica (Busck) (Lepidoptera: Tortricidae) in Pinus contorta Dougl. stands of Alberta. The Canadian Entomologist, 117: 1463-1470.

Wong, H.R., Drouin, J.A., and Rentz, C.L. 1995. Pitchblister moths, Petrova spp. In Forest insect pests in Canada. Edited by J.A. Armstrong and W.G.H. Ives. Natural Resources Canada, Canadian Forest Service, Ottawa, Ontario, Canada. Pp. 279-288.

Wood, C.S. and Van Sickle, G.A. 1986. Forest insect and disease conditions, British and Yukon 1985. Information Report BC-X-277. Canadian Forest Service, Pacific Forest Research Centre, Victoria, British Columbia, Canada.

Wood, C.S., Van Sickle, G.A., and Shore, T.L. 1984. Forest insect and disease conditions, British and Yukon 1983. Information Report BC-X-246. Canadian Forest Service, Pacific Forest Research Centre, Victoria, British Columbia, Canada.

Yemshanov, D., McKenney, D.W., de Groot, P., Haugen, D., Pedlar, J., Sidders, D., et al. 2011. A harvest approach to assess the threat from an invasive species. Journal of Environmental Management, 92: 205-213.

Zethner-Møller, O. and Rudinsky, J.A. 1967. On the biology of Hylastes nigrinus (Coleoptera: Scolytidae) in western Oregon. The Canadian Entomologist, 99: 897-911. 